\title{
La conflictividad social en Palencia desde 1421 hasta la guerra de las Comunidades*
}

\author{
Asunción Esteban Recio \\ Universidad de Valladolid
}

RESUMEN: Durante la Guerra de las Comunidades, en Palencia se produjo la toma del poder municipal por el bando comunero, que integraba a la mayoría de la población. Un hecho tan excepcional tiene su explicación en la conflictividad de la urbe en el siglo $X V$, que determinaría el declive del señorío episcopal, cuyo dominio sobre Palencia se remontaba a comienzos del siglo XI. La ciudad mantenía la reivindicación secular de integrarse en el ámbito del realengo para desvinculare del poder episcopal. Pero los conflictos entre el señorio, el concejo y los distintos grupos sociales provocaron constantes enfrentamientos, que adquirieron mayor virulencia con el creciente protagonismo del común, movilizado tanto contra los abusos del señor como contra los más poderosos de la ciudad, que rivalizaban por monopolizar el concejo. Esa constante conflictividad llevó a la intervención cada vez más frecuente de la corona en detrimento de la autoridad señorial, cuyo declive facilitó el fortalecimiento de la oligarquía local. La derrota comunera desarboló la lucha por la autonomía de la ciudad que, finalmente, se integraría en el realengo con Felipe II.

\section{PAlABRAS ClAVE: Historia social; Conflicto; señorío episcopal; con- cejo; poder real; común; Comunidades.}

* El presente trabajo recoge algunos resultados obtenidos en el transcurso del proyecto de investigación «Impacto urbano, actividad productiva y sociabilidad en las villas y ciudades del eje económico Toledo-Burgos (1450-1520)» Referencia HAR2010-15422, dirigido por María Asenjo-González y financiado por el Ministerio de Ciencia e Innovación (MICINN). Las siglas utilizadas para la fuentes documentales son: Archivo Municipal de Palencia (AMP), Libro de Actas Municipales (LAM), Archivo de la Catedral de Palencia, (ACP), Archivo de la Real Cancillería de Valladolid (ARCHV), Archivo General de Simancas (AGS) Registro General del Sello (RGS), Cámara Pueblos (CP). 


\section{Social unrest in Palencia from 1421 to the War of the Communities.}

ABSTRACT: During the War of the Communities of Castile, there took place in Palencia the taking of power by the comunero party, which happened to include the majority of the population. Such an exceptional event can be accounted for by the city's high level of conflict throughout the fifteenth century - a fact that would determine the decline of the bishop's seigneurial domain dating back to the early eleventh century. The city still retained its century-old claim to become part of the royal domain and thus free itself from the rule of bishops. However, the disputes involving the seigneurial power, the council and the several social groups eventually led to a state of steady confrontation which became even more heated as a result of the growing protagonism of the commoners. The latter actively opposed the misuse of power by the lords and the ways of the most powerful ranks of urban society that rivaled over the exclusive control of the local council. In fact, unremitting conflict led to an ever more frequent intervention by the Crown in the detriment of seigneurial power, whose decline in turn entailed the strengthening of the local oligarchy. The defeat of the comunero cause ultimately dismantled the struggle for the city's self-rule, so that Palencia eventually subsided into the royal domain during the reign of Philip II.

KEY WORDS: Social History; Conflict; Episcopal lordship; town council; royal power; common; Community.

La historiografía sobre la conflictividad social experimentó un proceso de auge durante la década de los 60 y $70^{1}$, que fue seguido de un breve declive durante los años $80^{2}$, para resurgir con fuerza a finales del siglo pasado ${ }^{3}$. A lo

${ }^{1}$ El panorama sociopolítico del periodo estuvo caracterizado por una intensificación de los conflictos, tanto en los países desarrollados como en el Tercer Mundo, que dio lugar a procesos de revolución social $\mathrm{y}$, como afirma I. Wallerstein, a una auténtica revolución cultural. Cabe mencionar por su carácter innovador la obra de MULLET, 1990. En ese contexto, historiadores vinculados a Annales y, en particular al materialismo histórico, se ocuparon en sus investigaciones del tema de los movimientos sociales: THOMPSON 1989. RUDÉ, 1971. HOBSBAWM, 1968. PORSHNEV, 1978. En el campo de la historia medieval, MACEK, 1975. MOLLAT y WOLFF, 1970. HILTON, 1978. Es imprescindible mencionar por su carácter innovador la obra de MULLET, 1990.

${ }^{2}$ El declive coincide con el cambio sociopolítico, marcado por el fracaso de las revueltas sociales de los años $60 \mathrm{y}$ la crisis del socialismo real, que dio paso a un periodo de conservadurismo político y a la implantación en las ciencias sociales de tesis como el fin de la Historia (Fukuyama), o el fin de las ideologías (Bell) y al triunfo del postmodernismo y el neopositivismo. El trabajo de PÉREZ LEDESMA, 1993: 141-189, ofrece una magnífica visión historiográfica sobre el tema de la protesta social.

${ }^{3}$ El renovado interés por el estudio de las acciones sociales está relacionado con lo que Barros denomina el retorno del sujeto histórico, en relación a las movilizaciones surgidas contra el «nuevo orden mundial». 
largo de ese proceso, la Historia Social ha experimentado una renovación temática y metodológica, especialmente visible en el campo de la historia de los movimientos sociales. La crítica a los esquemas estructuralistas y al determinismo económico, que había caracterizado a los estudios sobre la conflictividad ${ }^{4}$, abrió paso a nuevos enfoques en los que se otorgaba un especial significado a los aspectos culturales e ideológicos y al papel desempeñado por las clases subalternas en la protesta social y, en última instancia, en los cambios históricos ${ }^{5}$. El campesinado y las clases populares urbanas, consideradas por la historiografía tradicional agentes pasivos o simples víctimas de la explotación de las clases dominantes ${ }^{6}$, adquirieron la dimensión de sujetos históricos, con conciencia política y capacidad para organizarse y articular sus reivindicaciones ${ }^{7}$.

Los historiadores españoles tardaron en conectar con las corrientes europeas, como consecuencia del estancamiento historiográfico que se produjo en nuestro país durante los años de la dictadura franquista. La normalización académica de la historia, con palabras de Josep Fontana, es decir, la apertura hacia las corrientes más avanzadas de la historiografía europea, no se inició hasta los años de la transición democrática. En ese contexto de intensa movilización, la investigación histórica adoptó una orientación preferentemente social, con especial interés hacia el tema de la conflictividad, que se prolongó hasta mediados de los años $80^{8}$. En consonancia con la historiografía europea de las últimas décadas, la historiografía española ha incorporado nuevas perspectivas de análisis en el estudio de los conflictos sociales y la protesta popular: formas de expresión, factores psicosociales y culturales, importancia del pacto social, ideología, conciencia y discurso del campesinado y la clase popular; solidaridades y fórmulas organizativas; papel desempeñado por la élite de los pecheros en las reivindicaciones del común, etc. ${ }^{9}$

${ }^{4}$ THOMPSON, (1981), califica el estructuralismo de Althusser de «teoricismo histórico» y FONTANA, (1982), de desnaturalización y dogmatismo" defendiendo la necesidad de una profunda «renovación».

${ }_{5}^{5}$ El grupo de Subaltern Studies sería el mejor exponente de este cambio, GUHA, 2002.

${ }^{6}$ La mayoría de tipologías que minimizaron el papel del campesinado utilizadas en las revueltas sociales han quedado obsoletas, FREEDMAN, 3 (Valladolid, 2000): 17-37.

7 J.C. Scott, C. Wickham, S. Justice y P. Freedman abordan el estudio de los conflictos antiseñoriales desde la perspectiva de las expectativas y referentes de las comunidades rurales.

${ }^{8}$ Entre los trabajos pioneros sobre la conflictividad social en la Edad Media en España cabe citar a VICENS VIVES, 1994. MARAVALL 1963. En la segunda mitad de los años setenta multiplicaron los estudios sobre las acciones colectivas: GUTIÉRREZ NIETO, 1973. PASTOR, 1973. VALDEÓN, 1975. PÉREZ, 1977. BECEIRO PITA, 1977. MORETA, 1978. SARASA SÁNCHEZ, 1981. ESTEBAN RECIO, 1985. MONSALVO ANTÓN, 1985. ORTIZ REAL, 1985.

${ }^{9}$ Las publicaciones más recientes aparecen citadas en el texto y en el apartado dedicado a la bibliografía. 
El presente trabajo está dedicado al estudio de los conflictos sociales urbanos en la Baja Edad Media ${ }^{10}$, tomando como escenario la ciudad de Palencia en el periodo que transcurre entre 1421 y 1521. A lo largo del siglo que culmina con la revuelta comunera, Palencia vivió el auge y el declive del señorío episcopal que había dominado la ciudad desde su restauración a principios del siglo XI. Durante esos cien años, la conflictividad social de Palencia mantuvo como denominador común la secular reivindicación de la ciudad por su inserción en el realengo. Pero detrás de ese objetivo, compartido por la mayoría de los vecinos, se hicieron patentes otros conflictos en los que la clase popular asumió la defensa de sus intereses tanto frente al obispo y cabildo, en el ejercicio de sus atribuciones señoriales, como frente a la aristocracia local, que intentaba hacerse con el monopolio del gobierno municipal. La lucha del común culminó en Palencia con la toma de poder de la ciudad durante la revuelta comunera.

\section{EL ESCENARIO DE LOS ACONTECIMIENTOS: UNA CIUDAD DE SEÑORÍO EPIS- COPAL}

Los conflictos sociales son una de las consecuencias de las relaciones entre clases con intereses antagónicos -verticales- y entre grupos rivales de la misma clase social -horizontales-. En ambos casos los objetivos que persiguen sus protagonistas son el reparto de la renta y la introducción de cambios en el sistema político ${ }^{11}$, lo que significa que todo conflicto social se inscribe, en última instancia, en el ámbito de las relaciones de poder ${ }^{12}$. El estudio de la conflictividad social requiere, por tanto, el análisis de la estructura social y del marco político e institucional en el que se desarrolla.

Palencia en la Edad Media tenía una particularidad que la singulariza respecto a las ciudades castellanas de su tiempo: su condición de señorío ecle-

${ }^{10}$ En la sociedad feudal el conflicto por excelencia era el que enfrentaba a señores y campesinos pero en las ciudades se reprodujo un conflicto de similar naturaleza: el que enfrentaba a la aristocracia urbana y al común. Las discusiones metodológicas y científicas acerca de la naturaleza de la ciudad medieval han sido tan frecuentes como las relativas a la naturaleza general de la sociedad feudal. El debate se dirime entre quienes defienden que el mundo urbano surgió como una realidad ajena al sistema feudal y los que afirman que la ciudad medieval fue una consecuencia del desarrollo de la sociedad feudal y se insertó en sus estructuras. Como exponente de ambas posturas pueden citarse al historiador belga H. Pirenne y su teoría de la ciudad como centro de la «revolución comercial», y como defensor de la segunda opción, es decir, de la ciudad inserta en el marco general de la sociedad feudal, al historiador inglés HILTON, 1988, 106-122.

${ }^{11}$ KULA, 1973, 69.

12 LORENZO CADARSO, 1996, 7. 
siástico. Esta realidad incidió de forma notable en la organización municipal y fue determinante en la articulación social de la ciudad.

El origen del señorío se remonta a la restauración de la antigua diócesis palentina y de la ciudad, a principios del siglo XI, por lo que la definición de la institución señorial fue paralela al propio desarrollo de la urbe ${ }^{13}$. El fuero de 1180 , otorgado por el obispo don Raimundo, establecía la obligación de los vecinos de prestar pleito homenaje cuando los nuevos obispos tomaban posesión de la mitra y del señorío de la ciudad ${ }^{14}$. Pero además, el prelado y el cabildo de Palencia recibieron de los reyes numerosos privilegios, monopolios y atribuciones jurisdiccionales, que se proyectaban sobre todas las esferas de la vida local ${ }^{15}$. Al mismo tiempo, la jerarquía eclesiástica ejercía en la ciudad la autoridad religiosa, lo que les proporcionaba medios extraordinarios, como la excomunión o el entredicho, para dominar a la población frente a cualquier intento de resistencia.

El concejo, como órgano representativo de la comunidad, asumía una serie de competencias fundamentales para la vida de la urbe, aunque su autonomía en el ejercicio de sus funciones estaba recortada por las prerrogativas del obispo sobre el nombramiento de los cargos municipales ${ }^{16}$. Este intervencionismo señorial generó tensiones permanentes entre las dos esferas de poder que, en ocasiones, desembocaban en conflictos entre el obispo y el concejo, y en otras, se manifestaron en enfrentamientos entre el prelado y los vecinos. La dialéctica entre los dos centros del poder local estuvo mediatizada a su vez por la intervención en la ciudad del poder real, que tuvo un carácter inicialmente arbitral ${ }^{17}$. Tanto el señorío como el concejo acudían a la autoridad real para fortalecer sus posiciones o dirimir sus disputas internas, pero los intereses centralizadores de la corona se manifestaron en un creciente intervencionismo real. Los

${ }^{13}$ La restauración de la sede palentina y la concesión del señorío de la ciudad se inscribe en el contexto de la irrupción política del monarca navarro, Sancho III el Mayor, en el condado de Castilla y en el reino de León.

${ }^{14}$ El Consuetudinario o Ceremonial de la Santa Iglesia de Palencia de don Juan de Arce describe todos los actos y protocolos que se realizaban con motivo del recibimiento de los nuevos prelados cuando tomaban posesión de la mitra y asumían la autoridad señorial sobre la urbe. ACP, Arm, IV, Leg. 4.

${ }^{15}$ Entre los privilegios concedidos por los reyes al prelado y al cabido palentino figuraban: la percepción de rentas, como la martiniega, marzadga, portazgo; parte de los tributos de las minorías religiosas; la exención fiscal de sus excusados; derechos sobre los pesos del concejo; monopolios sobre la pesca, vendimia y venta de vino; explotación del monte y dehesa de la ciudad, cuya propiedad compartía con el concejo.

${ }^{16}$ Sobre las relaciones entre el señorío y la ciudad: ESTEBAN RECIO, 1989. Un estudio general sobre la ciudad de Palencia en la Baja Edad Media nos lo ofrece, FUENTE PÉREZ, 1989.

${ }_{17}$ Merece destacarse en este apartado los trabajos de NIETO SORIA: 1983, 1:285-294. Centrado en las relaciones entre la monarquía y el episcopado y las relaciones de poder en Palencia: NIETO SORIA, 6, (Madrid, 1985): 625-640. 
constantes disturbios y enfrentamientos entre el señorío y la ciudad favorecieron la presencia en Palencia de delegados regios que acudían con el objetivo de restablecer el orden ciudadano ${ }^{18}$, de tal forma que lo que comenzó siendo una intervención ocasional se convirtió en permanente con la institucionalización de la figura del corregidor en el último cuarto del siglo XV.

La articulación social de Palencia no difería en lo sustancial de la que caracterizaba a otras villas y ciudades de Castilla ${ }^{19}$, aunque presentaba algunos matices importantes derivados de la preponderancia de la Iglesia en la vida social y política de la urbe ${ }^{20}$. Las jerarquías eclesiásticas (obispo, arciprestes, canónigos, etc.) ostentaban una posición más relevante que en otros núcleos urbanos por la influencia del señorío. La posición social de la Iglesia y el poder que ejercía sobre la ciudad estaban directamente relacionados con el interés de los sectores más encumbrados de la sociedad palentina por integrar a sus familias en el cabildo y establecer vínculos vasalláticos o clientelares entre la élite eclesiástica y la aristocracia urbana ${ }^{21}$.

Si en las ciudades de realengo la caballería local era el grupo social más relevante, en Palencia su fuerza se vio mermada por el peso específico de los sectores eclesiásticos y las atribuciones del señorío episcopal. En una posición muy cercana a los caballeros se encontraban los que figuran en la documentación con los términos de caudalosos o ciudadanos abonados. Se trataba, sobre todo, de gentes enriquecidas con la práctica del comercio y la artesanía, particularmente relacionadas con la producción textil, actividad que había convertido a Palencia en uno de los núcleos pañeros más destacados del reino ${ }^{22}$. Las fronteras entre ambos grupos no estaban bien definidas, ya que los acaudalados podían adquirir el estatus de caballeros a través de la cuantía de sus bienes, la política matrimonial o la conversión en excusados del cabil-

18 Respecto a la incidencia en la ciudad de la intervención real pueden consultarse: JARA FUENTE: 2008: 211-240 y GUERRERO NAVARRETE, 2008: 241-279.

${ }^{19}$ En los últimos años se han publicado numerosos trabajos dedicados a sociedades urbanas y espacios de poder: ASENJO-GONZÁLEZ, 5, (Madrid, 1995): 103-108. CARLÉ, FAUVE, et al., 2001. GUERRERO NAVARRETE, 2008:241-279. ESTEPA DIEZ, 2011: 75-95. IGLESIA DUARTE y MARTÍN RODRÍGUEZ, 2002. Una visión de la sociedad urbana, tomando como eje de análisis al común: RUBINSTEIN, 2005.

${ }^{20} \mathrm{La}$ Iglesia era la principal propietaria de bienes inmuebles de la ciudad, VALDEÓN BARUQUE y ESTEBAN RECIO III/2 (Salamanca, 1985): 117-141.

${ }^{21}$ Sobre las vinculaciones entre la gentry y el señorío episcopal es ilustrativo el caso de la ciudad inglesa de Durham durante el siglo XV, LIDDY, 2008.

${ }^{22}$ Los tejidos palentinos, aunque de baja calidad, se vendían en las principales ferias y mercados del reino y, según E. Larruga, a finales del siglo XVIII llegaban hasta las colonias: No se puede negar que Palencia debe reputarse por la provincia más industriosa de Castilla, pues sus tejidos de estameñas, mantas, cobertores y algún otro artículo de lana, llega hasta las Américas», citado por HERNÁNDEZ GARCÍA, 2007: 12. Puede consultarse también: OLIVA HERRER, (Salamanca 2000-2001), 18/19: 225-251. 
do durante el tiempo suficiente para demostrar su condición de exentos ${ }^{23}$. Ambos, caballeros y acaudalados, constituían el patriciado de la ciudad. Se trataba, por tanto, de una aristocracia que debía su fortuna al desempeño de actividades profesionales más que al oficio militar o a la posesión de bienes territoriales. Próximos a este patriciado urbano se encontraban los denominados en las fuentes como hombres buenos ${ }^{24}$, que podemos identificar con la capa superior de los pecheros ${ }^{25}$. Los hombres buenos se integraban en la clase popular, con la que compartían su condición de contribuyentes, pero con una posición económica que les aproximaba a la aristocracia local.

Esta permeabilidad de las estructuras verticales se vio favorecida por la presencia del señorío. Las atribuciones que ejercía el obispo en el nombramiento de los cargos del concejo confirieron a la vida política de la ciudad un mayor dinamismo que, sin embargo, no estuvo exento de choques entre las dos instancias de poder que trataban de delimitar sus atribuciones, y de enfrentamientos internos entre los grupos sociales que se disputaban la presencia en el gobierno municipal. Tal como establecía la sentencia de 1352, firmada por Pedro I, el prelado tenía el privilegio de elegir a cuatro alcaldes y doce regidores para que se encargaran del gobierno de la ciudad, exclusivamente durante un año. La asamblea general del concejo, por su parte, tenía el derecho de proponer candidatos para la nominación, mediante un procedimiento que fue redefiniéndose a lo largo del siglo $\mathrm{XV}$, según la fuerza y los intereses de los grupos sociales en liza por el poder político local, en detrimento de la intervención de los vecinos en los comicios. Este sistema contrastaba con lo que sucedía en otras villas y ciudades, donde era el propio monarca quien nombraba a los regidores, y los cargos tendieron a convertirse en vitalicios y hereditarios ${ }^{26}$.

En Palencia, sin embargo, la obligatoriedad de la renovación anual de los oficios de alcaldes y regidores limitaba su perpetuación en el cargo y, en última

${ }^{23}$ El obispo y los canónigos palentinos tenían el privilegio de excusar de entre la población pechera a sus protegidos. Como la elección solía recaer en las mismas personas, los beneficiados se convirtieron en una pequeña élite local, con posibilidades de promoción social. POLANCO PÉREZ, 2003: 221.

${ }^{23}$ ESTEBAN RECIO A. e IZQUIERDO GARCÍA, X, (Salamanca, 1992): 111-146.

${ }^{24}$ En 1491 una disposición de los Reyes Católicos obliga a los regidores y justicias reales del concejo que presenten las cuentas de los bienes y rentas de propios ante un representante del estado de los caballeros, otro de los ciudadanos y otro de los hombres buenos pecheros. (AMP), Provisión Real, 1490, Libro de Provisiones, fols. 9v-10, citado por VALLE CURIESES, DEL, 2007: 131.

${ }^{25}$ Sobre la capa superior de los pecheros como clase emergente: DEL VAL VALDIVIESO, (Alicante, 1988-1989); 193-224.

26 TOMẢS Y VALIENTE, 1970: 141-142. Uno de los primeros en afirmar que las oligarquías locales no estaban constituidas exclusivamente por sectores de la baja nobleza, fue GONZÁLEZ ALONSO, 1982: 57-85. En relación a las consecuencias de la implantación del regimiento en la formación de oligarquías locales en las ciudades castellanas: DEL VAL VALDIVIESO, 1994 41-58. 
instancia, dificultaba la formación de una oligarquía al frente del concejo, similar a la que existía en las ciudades de realengo ${ }^{27}$. Eso no significa que los sectores más poderosos de la sociedad palentina no trataran de hacerse con el control del concejo recurriendo a todos los medios a su alcance. La cercanía a las jerarquías eclesiásticas $\mathrm{y}$, en especial al obispo, fue una de las vías más utilizadas por los grupos de poder para garantizar su presencia en el concejo, ya que, en última instancia, era el prelado quien otorgaba los cargos. Pero el intento de enquistamiento en el poder de la clase dirigente fue abortado en muchas ocasiones por la clase popular, que contaba con sus procuradores e instituciones organizativas —oficios, cofradías y vecindades - para defenderse de los abusos de los poderosos y plantear sus propias reivindicaciones ${ }^{28}$.

\section{La Conflictividad social en Palencia}

El reino de Castilla no fue ajeno a los interminables conflictos políticos y sociales que se extendieron por Europa occidental vinculados a la crisis del siglo XIV ${ }^{29}$. Pero la conflictividad en Palencia, aunque responde a ese contexto y a los avatares de la corona castellana, reúne características peculiares por tratarse de una ciudad de señorío episcopal ${ }^{30}$. La urbe del Carrión estaba bajo el dominio de los obispos palentinos desde su fundación, pero la ciudad nunca aceptó de buen grado su poder, como lo prueban los numerosos conflictos que se sucedieron a lo largo de la Baja Edad Media. La pugna entre el obispo y el concejo fue una constante de aquellos siglos, porque la ciudad siempre quiso emanciparse del señorío episcopal. La reivindicación de la autonomía municipal frente a los privilegios señoriales y las protestas de los palentinos por los abusos de poder por parte de los obispos acabaron, con frecuencia, en estalli-

${ }^{27}$ Sobre la formación y consolidación de las oligarquías en las ciudades castellanas: VALDEÓN BARUQUE, 1990: 507-537. BONACHÍA HERNANDO y MARTÍN CEA, 9 (Córdoba, 1998): 17-40. ASENJO-GONZÁLEZ, 2006: 133-196.

${ }^{28}$ En relación a la composición y organización del común: ASENJO-GONZÁLEZ, 2004, 181-194; DEL VAL VALDIVIESO (1994), Destaca el papel desempeñado por las asambleas concejiles abiertas y el papel representativo de los procuradores del común.

${ }^{29}$ Sigue siendo un referente en el estudio de la conflictividad social el trabajo de VALDEÓN BARUQUE, 1983; 2002. Sobre la conflictividad social urbana en el periodo del reinado de Enrique IV, ESTEBAN RECIO, 1985; una aportación a la cuestión de las ideologías en los conflictos sociales: BARROS, 1990; centrados en la conflictividad social en el siglo XV: DEL VAL VALDIVIESO, 26, (Barcelona, 2005): 1033-1050. VALDEÓN BARUQUE, (2002). NARBONA VIZCAÍNO, 2002. IGLESIA DUARTE, 2003; sobre los distintos instrumentos de la lucha política: NIETO SORIA, 2004, 14: 165-204.

${ }^{30}$ El estudio de RUÍZ DE LA PEÑA, 2004, 14: 113-146 está dedicado a la conflictividad en ciudades de señorío eclesiástico, aunque se centra en un período anterior al que constituye el marco cronológico de este trabajo. 
dos de violencia. Algunos de los enfrentamientos más graves coincidieron con períodos en que la conflictividad política del reino era más aguda, y el obispo y la ciudad podían apoyar respectivamente a los grupos en liza. Otras veces, se trataba de conflictos de naturaleza vertical entre el común y el concejo, en el que estaban representados fundamentalmente los grupos sociales dominantes. Y por último, se produjeron también conflictos de intereses de sesgo horizontal entre los propios sectores de la aristocracia local. Las luchas tuvieron un marcado carácter social y político, aunque, en ocasiones, los aspectos económicos podían pasar a un primer plano, como sucedió con las luchas entre los tejedores y los mercaderes de la ciudad.

\section{La revuelta de 1421. La lucha del común contra la élite de poder}

El fortalecimiento que había experimentado el señorío episcopal en el transcurso de la segunda mitad del siglo XIV y comienzos del XV se vio frenado en las décadas posteriores por conflictos que pusieron en cuestión el poderío de los obispos. Los enfrentamientos más importantes tuvieron lugar entre 1421 y 1423 y desde 1447 a $1452^{31}$. En los dos períodos se reprodujo la vieja lucha entre el obispo y el concejo, que pretendía, como institución representativa de los vecinos, la inserción de la ciudad en el ámbito del realengo como medio para desvincularse del señorío episcopal. Pero lo que singulariza a estos conflictos con respecto a los de la centuria anterior es el protagonismo del común, que se enfrentó tanto al obispo como al concejo, puesto en cuestión por no defender con firmeza los intereses de los vecinos frente al señor de la ciudad.

El contexto político en la década de los 20 estuvo marcado por el enfrentamiento, en el reino de Castilla, entre los infantes de Aragón y don Álvaro de Luna, el poderoso valido del rey Juan II. El obispo de Palencia, don Rodrigo de Velasco, tomó partido por los infantes, y la ciudad, hostil al prelado, abanderó la causa realista ${ }^{32}$. La coyuntura fue aprovechada inmediatamente por el concejo para reivindicar el derecho de «Voz» en Cortes, que ejercía el obispo como señor de la ciudad ${ }^{33}$. La reclamación, que fue gestionada en la Corte por

${ }^{31}$ ESTEBAN RECIO, 1989; 172-185.

32 Para la toma de posición en el conflicto político del reino se celebró una reunión extraordinaria del concejo en la iglesia de San Miguel, en la que los vecinos introdujeron de forma velada una serie de normas que limitaban la intervención señorial en el concejo y las atribuciones propias del regimiento.

${ }^{33}$ En 1422, la ciudad aprovechó el apoyo prestado a Juan II, para solicitar en las Cortes de Ocaña la inserción del Palencia en el realengo: A lo que me pedistes por merçet diciendo que bien sabía o podía saber en commo entre la mi çibdat de Palencia e los obispos que della fueron e son se avia tractado e tractaba pleito, grant tiempo, avía sobre algunos derechos quelos dichos obispos dezían aver enla dicha cibdat, delo qual se avía segido e seguía al cibdat 
procuradores de la urbe, contaba con el apoyo del conjunto de los vecinos, pero la mala gestión del concejo en los conflictos que se produjeron con el obispo provocaron el rechazo del común hacia los magistrados locales ${ }^{34}$.

El conflicto comenzó por un motivo aparentemente menor: el arrendamiento por el concejo, sin notificación previa, del monte y la dehesa de la ciudad, que tenía en propiedad conjunta con el cabildo. No era la primera vez que había discordias con los canónigos por esa causa. El concejo y el cabildo mantenían una vieja pugna por el monte, pero, en esta ocasión, el obispo respondió con extrema dureza: excomulgó a los alcaldes y regidores junto con otros vecinos y decretó el entredicho en la ciudad, lo que significaba la suspensión de todos los oficios religiosos. La represalia del prelado encrespó los ánimos de la gente del común y el concejo emplazó al cabildo en la Corte.

La concesión real de la voz para la ciudad llegó después de una reunión extraordinaria del concejo en la iglesia de San Miguel, a la que asistió la mayor parte de la población, con el fin de aprobar unas ordenanzas en favor de la causa realista y de prohibir, incluso bajo pena de muerte, el apoyo a cualquier seglar o eclesiástico partidario de los infantes rebeldes ${ }^{35}$. La reunión popular fue aprovechada por el común para introducir de forma velada algunas normas que limitaban la intervención señorial en el concejo y las atribuciones del regimiento ${ }^{36}$. La reacción del obispo no se hizo esperar; emprendió gestiones para recuperar la representación de la ciudad en las Cortes, excomulgó a una larga lista de personas, exigió la revocación de las ordenanzas de San Miguel y prohibió la celebración de este tipo de asambleas ${ }^{37}$. De esa forma, el prelado

muchas costas e daños e se va a peder e despoblar; por ende me suplicavades que me pluguiese de aver informaçión plenaria de los tales derechos que los dichos obispos e eglesia diz aver en la dicha çibdat, que les mande contentar en otra parte en dinero, en tal manera que la dicha çibdat quedase libre e quita a la mi corona rreal, e non fuese enajenada a los dichos obispo e eglesia. AMP, LAM, 26-O1- 1423.

${ }^{34}$ En el siglo XV, se restringió a 17 (18 a partir de 1492) el número de ciudades con voz en Cortes. Los núcleos que consiguieron mantener ese privilegio se erigieron en centros de poder con capacidad para representar a ciudades que no tenían el derecho de voz.

35 Algunas personas de la ciudad mantenían vínculos de vasallaje con Pedro Manrique, señor de Amusco, favorable a los aragoneses.

${ }^{36}$ En la reunión de San Miguel se acordó que el merino, que en Palencia era nombrado por el obispo, sólo podría prender a los vecinos con mandamiento de los alcaldes; así mismo se prohibió que los oficiales del concejo pudieran revelar al obispo los acuerdos y, por último, se estipuló que los alcaldes sólo pudieran ordenar hacer una pesquisa en la ciudad si contaban con el respaldo del concejo y los vecinos, ESTEBAN RECIO, 1989:176.

${ }^{37}$ En Palencia era muy frecuente la celebración de reuniones extraordinarias, convocadas en unos casos por el concejo, para tratar asuntos que afectaban al conjunto de la ciudad, y en otras ocasiones directamente por los vecinos, generalmente a iniciativa a la clase popular. Como ha destacado J. M Monsalvo el movimiento asambleario tuvo tanta fuerza en Palencia que la voz de concejo no alude al regimiento sino a la asamblea vecinal. MONSALVO ANTÓN, 7 (Salamanca, 1987):5-8. 
pretendía cortar de raíz la participación popular en un conflicto que atentaba contra su poder y el de los alcaldes nombrados por él mismo.

A pesar de la actitud sumisa al señorío manifestada por algunos cargos municipales, el concejo y los distintos grupos sociales de la ciudad habían permanecido unidos frente al obispo. Sin embargo, la situación cambió diametralmente a raíz de los sucesos ocurridos durante la vendimia del obispo. Entre otras cargas, los vecinos estaban obligados a respetar el privilegio señorial del estanco del vino, que permitía al prelado vendimiar de forma exclusiva durante dos días y vender sus cubas, sin competencia, en los ocho días siguientes. Aunque el privilegio dañaba claramente los intereses económicos de la ciudad, no fue la existencia misma del monopolio señorial lo que desató el conflicto, sino la violencia empleada para hacerlo cumplir, sin que los oficiales tomaran cartas en el asunto ${ }^{38}$. Ante la pasividad de los representantes del concejo, las masas populares se levantaron violentamente contra los eclesiásticos, y los procuradores del común demandaron en la Corte al obispo por los abusos cometidos en el ejercicio de su autoridad y a los alcaldes por negligencia en el cumplimiento de la justicia. La demanda tenía un profundo calado político, porque quienes iniciaron el pleito en Toledo eran hombres buenos enriquecidos que constituían un grupo rival de los alcaldes y regidores.

A pesar de las limitaciones que imponía la convocatoria anual de elecciones municipales, en la práctica se había ido creando una élite de poder con presencia continuada en el concejo y, por tanto, próxima al señorío eclesiástico, que era quien elegía a los candidatos propuestos por la ciudad para los cargos municipales. Prueba de ello es que, sin haberse resuelto el conflicto iniciado en la Corte, en las elecciones de 1422 el obispo seleccionó a un significativo número de candidatos que habían desempeñado cargos en el regimiento el año anterior. El concejo, presionado por el obispo, intentó negociar la retirada del pleito a cambio del perdón para sus promotores, pero el acuerdo fracasó y terminó con la presencia del corregidor, por primera vez, en $\mathrm{Pa}$ lencia. Gómez Díaz de Vasurto llegó con poderes del rey para realizar una pesquisa por un plazo de seis meses, asumiendo las funciones judiciales de los alcaldes ordinarios, y con potestad para nombrar a un merino que ejecutase sus decisiones. Durante su mandato cesó la violencia en las calles, y los procuradores y vecinos que mantenían el pleito en Toledo, hasta entonces desterrados, pudieron volver a Palencia, sin retirar la demanda en la Corte. El nombramiento del hermano del corregidor como merino fue recusado por el obispo al considerarlo una intromisión en sus atribuciones, y la prórroga de

${ }^{38}$ La causa del estallido del conflicto fue que los hombres del obispo, por la fuerza de las armas, habían prendido las mulas de los vecinos que andaban a vendimiar queriéndolos matar. AMP, LAM, 18-10-1421. 
tres meses concedida por el rey para terminar la pesquisa desembocó en un enfrentamiento abierto entre las tres instancias de poder.

El obispo amenazó con excomulgar a los alcaldes, regidores y vecinos que aceptasen la prolongación del mandato del corregidor, tal y como ocurrió. En respuesta, el corregidor llamó a las armas a los vecinos en favor de la justicia del rey, dado que el prelado se había opuesto a una decisión regia y pretendía involucrar en su rechazo al concejo y a los palentinos. La tensión creció hasta el punto que gentes de armas tomaron el alcázar de la ciudad.

Al final de la prórroga del mandato de Díaz de Vasurto, el concejo de común acuerdo con los vecinos, rechazó la llegada de un nuevo corregidor, por el elevado coste económico que comportaba su presencia. Cuando la ciudad se apaciguó definitivamente, el concejo reapareció como el primer valedor de la legalidad vigente, advirtió a los vecinos que no podrían ejercer su derecho a celebrar asambleas sin solicitarlo previamente al gobierno municipal, y manifestó al obispo que el concejo no tenía más litigios con el señorío que el pleito por la jurisdicción de realengo, en el cual están todos los debates que de una parte e otra eran o son $^{39}$.

\section{La lucha de los pecheros por la participación en el gobierno municipal (1447 a 1452)}

Si en 1421 el levantamiento popular se produjo como respuesta a la represión señorial, el conflicto de 1447 tuvo su origen en el abuso de las prerrogativas del obispo sobre el sistema electoral, que regulaba la renovación anual de los cargos locales, y en la falta de representatividad de los intereses de la ciudad por parte de los alcaldes y regidores del concejo.

La revuelta de 1421 abrió una fisura en el concejo que permitió el acceso a los cargos municipales de algunos miembros destacados del estamento popular ${ }^{40}$; de hecho, en la lista de oficiales del concejo de 1424 aparecían casi todos los procuradores y portavoces del común que habían mantenido la demanda en la Corte. Sin embargo, la presencia del grupo de los pecheros en el gobierno se fue reduciendo a medida que aumentaba la influencia de los caballeros, muchos de ellos procedentes de las capas más elevadas de la clase popular. Su fortuna y el acceso a los cargos locales les había abierto las puertas a la caballería local, integrada por estirpes que, al igual que ellos, se habían enriquecido con la actividad textil de Palencia a lo largo de generaciones. Por

${ }^{39}$ ESTEBAN RECIO, 1989: 184-186.

${ }^{40}$ Respecto a las aspiraciones políticas de la elite del común: DEL VAL VALDIVIESO, 1996; 213-254; SOLÓRZANO TELECHEA, 14 (Valladolid 2013): 239-257; RUBINSTEIN, 2005. 
tanto, el acceso al gobierno municipal no era solo una vía para reforzar sus intereses económicos, sino para su progresión social ${ }^{41}$.

En Palencia, las relaciones de parentesco y clientelismo entre los eclesiásticos y las familias principales ${ }^{42}$, la ambición de los caballeros por hacerse con el gobierno de la ciudad y, por último, el poder de los obispos para nombrar alcaldes y regidores proclives a sus intereses, se tradujo, en la práctica, en la corrupción del sistema electoral en perjuicio de los pecheros. Pero en los años medios del siglo XV el común inició una lucha sin precedentes tanto para modificar en su provecho la representación política, monopolizada por la clase dirigente, como para garantizar una justa distribución de las cargas fiscales frente a los privilegiados. El instrumento que permitió a la clase popular llevar adelante sus reivindicaciones fue la Cofradía del Cuerpo de Dios ${ }^{43}$. No se trataba de una corporación profesional, sino de una institución de carácter asistencial que agrupaba a vecinos del barrio de La Puebla en el que residían un gran número de artesanos trabajadores del textil ${ }^{44}$. El carácter popular de la institución fue aprovechado por el común como plataforma para canalizar sus reivindicaciones sociales y políticas ${ }^{45}$. A mediados del siglo $\mathrm{XV}$, según la documentación de la época, se agrupaban en esa cofradía más de mil pecheros, de tal manera que «parescían más ser confederación e ligas que non cofradías» ${ }^{46}$.

${ }^{41}$ La evolución de la familia palentina de La Rúa es una muestra de la fluidez que caracterizaba a la sociedad de la Ciudad del Carrión. Los Rúa eran de origen judío y se dedicaban preferentemente al comercio de paños, lo que les permitió acumular una sólida fortuna. Tras su conversión a principios de siglo, los acaudalados traperos consiguieron integrarse rápidamente en la clase dirigente, desempeñando cargos en el concejo desde 1436. Su poder económico y político, unido a la estrategia familiar, les permitió ascender en la escala social e insertarse en la caballería local, ESTEBAN RECIO e IZQUIERDO GARCIA, 10 (Salamanca, 1992):101-48; CABEZA RODRÍGUEZ, 1995: 101-127. Sobre el papel de los judeoconversos en las ciudades castellanas puede consultarse, entre otros, el artículo de MUÑOZ SOLLA, 22 (Madrid, 2009): 207-228; En Granada, la clase dirigente estaba integrada por un $40 \%$ de personas de origen judeoconverso frente al 31\% de hidalgos, PEINADO SATAELLA, 14 (Valladolid, 2013): 215.

42 Acerca del clientelismo como instrumento de promoción social: ASENJO-GONZÁLEZ, 12, (Southampton, 1986): 167-182; 2009a.

${ }^{43}$ ESTEBAN RECIO 2, (Palencia, 1990): 569-599.

${ }^{44}$ GONZÁLEZ ARCE, 2009.

45 Además de las cofradías, la clase popular utilizó como marco organizativo las agrupaciones vecinales: collaciones, cuadrillas y parroquias, que contaron como cauce de acción política con la presencia en los concejos de los procuradores del común. La vecindad fue, según I. del Val, una marca de distinción que contribuyó a dotar de personalidad a la sociedad urbana, DEL VAL VALDIVIESO, 11 (Santander, 2006): 6 y 9.

${ }^{46}$ ESTEBAN RECIO, 1989: 192. En San Sebastián, las cofradías se consolidaron como plataformas de defensa de los intereses del común, capitaneadas por sectores intermedios que intentaban acceder al gobierno municipal, TENA GARCÍA (Salamanca, 2013): 231-254. En torno al papel de las cofradías como elemento de conexión y creación colectiva de identidad del común, DIAGO HERNANDO 68/1 (Madrid, 2013): 33-56. 
Llegado el primer domingo de marzo de 1447, como establecía el régimen electoral palentino, se ayuntó el concejo en pleno a las puertas de la iglesia de San Antolín para iniciar los comicios locales con la elaboración de una lista de veinte hombres buenos, encargados de proponer candidatos para las alcaldías y regidurías. De esa nómina, el prelado elegía doce regidores y, de una lista más restringida, cuatro alcaldes. Unos y otros permanecían en sus cargos durante un año. Pero en aquella sesión no figuraban entre los propuestos ninguno de los oficiales del año anterior, y la nómina de candidatos a las alcaldías se había reducido hasta el punto de que el prelado no tenía capacidad de elección ${ }^{47}$. Ninguna norma prohibía que los nombrados para un año volvieran a ser candidatos el siguiente, como tampoco se especificaba el número mínimo de la candidatura para las alcaldías. Pero el obispo, don Pedro de Castilla, rechazó la lista propuesta por la ciudad y, como medida represiva, excomulgó a la asamblea vecinal y decretó el entredicho en la urbe. Desde ese momento se inició un largo conflicto en el que el común asumió la iniciativa tanto contra el obispo, por extralimitarse en el ejercicio de sus atribuciones, como contra la élite política que dominaba el concejo. Las propuestas populares se articularon en tres reivindicaciones fundamentales: mayor participación en el gobierno municipal, distribución más justa de las contribuciones impositivas y mayor transparencia fiscal.

Para contrarrestar la creciente presión de los pecheros, la nobleza creó la Cofradía de San Antón como organización emblemática de los caballeros locales. Hubo numerosos enfrentamientos a lo largo de aquel año, pero el más violento, sin duda, fue el que desembocó en el incendio de la torre de Monzón, propiedad del señorío. Tras este conflicto, la ciudad consiguió una de sus principales demandas: que los alcaldes y regidores del concejo sólo pudieran ser reelegidos cuando hubiera transcurrido un año del final de su mandato, lo que limitaba su permanencia en el poder. La sentencia de 1452, que puso fin al enfrentamiento, modificó, además, el régimen electoral vigente en Palencia desde 1352. Justo un siglo después se dispuso que en el futuro la asamblea general del concejo designara a dos procuradores, uno del estamento de los pecheros y otro del estado de los caballeros, escuderos, exentos y privilegiados, para que entre los dos eligieran a los veinte hombres buenos encargados de proponer candidatos para el nombramiento por el obispo de los oficiales del regimiento. Esta cláusula limitaba la posibilidad de que el gobierno de la ciudad quedara monopolizado por cualquiera de los dos estamentos, y expresaba la rivalidad existente entre caballeros y pecheros enriquecidos por el poder municipal, que acabaría pasando al primer plano en las décadas siguientes.

${ }^{47}$ La causa del veto de los vecinos fue que durante la vendimia los alcaldes y regidores habían permitido al obispo que fijara el precio del vino sin su intervención y que vendiera más cubas de las autorizadas, lo que significaba que habían hecho una dejación de sus funciones en defensa de los intereses de la ciudad, ESTEBAN RECIO, 1989: 189. 
La intervención del común en el concejo quedó garantizada a través de una serie de normas que afectaban a su participación en la gestión de la hacienda municipal y en la distribución de las cargas fiscales. Los diputados del común, representantes de los distintos sexmos de la ciudad, serían los encargados de supervisar los gastos e ingresos del concejo y los tributos recaudados. Asimismo, se establecía que tanto las derramas extraordinarias como las desgravaciones fiscales debían hacerse con su aprobación. Tradicionalmente la elección de los diputados pecheros correspondía a los procuradores del común, pero la sentencia introdujo la novedad de que, en adelante, sería la asamblea general del concejo, convocada para los comicios, la que tendría esa atribución.

La sentencia concluía con una orden que dejaba a la clase popular sin medios organizativos para la defensa de sus intereses y prohibía la celebración de ayuntamientos que no fueran oficiales. Así, aunque no se establecía la desaparición de la Cofradía del Cuerpo de Dios, su existencia quedaba limitada al número de cofrades que tenía primera mente e non sea más acrecenta$d a \ldots$ y especificaba que debía volver a su sentido y composición originales. A cambio la cofradía de San Antón, creada exclusivamente para contrarrestar la organización de los pecheros, fue disuelta ${ }^{48}$.

\section{5-1486. El declive del señorío y el ascenso del poder real}

Durante la segunda mitad del siglo XV los constantes enfrentamientos entre la ciudad y el obispo, así como las pugnas existentes entre los grupos sociales por el control del concejo, propiciaron una intervención creciente del poder real en la ciudad.

Los conflictos se iniciaron en 1462, coincidiendo con el episcopado de don Gutierre de la Cueva, especialmente odiado por los vecinos por su autoritarismo en el ejercicio de las atribuciones señoriales. Las tensiones se recrudecieron durante los años de la guerra que enfrentó a Enrique IV con su hermanastro, el príncipe don Alfonso, que fue proclamado rey por un sector de la nobleza en la llamada farsa de Ávila de $1465^{49}$. Los enfrentamientos nobiliarios y las divisiones del reino solían ser periodos propicios para resucitar viejos pleitos y reactivar tensiones latentes en las ciudades. En Palencia, el obispo, hermano de Beltrán de la Cueva, se mantuvo fiel a Enrique IV, mientras que la ciudad se decantó por el bando rebelde. La adhesión de la urbe del Ca-

48 ESTEBAN RECIO, 1989: 192.

${ }^{49}$ De este señor obispo descienden muchos caballeros, que se llaman de Castilla; su hijo... hizo casa en esta ciudad de Palencia, donde sus herederos tienen su principal asiento y capilla muy honrada y enterramientos en la iglesia de San Lázaro, FERNÁNDEZ DE MADRID, 1973:309 
rrión a la causa de Alfonso estuvo liderada por don Sancho de Castilla, hijo del anterior obispo don Pedro. El prelado contó con el apoyo de los conversos -prinçipales de la Calle Pan y Agua- muchos de ellos acaudalados mercaderes de paños con presencia en el concejo; mientras que don Sancho contó con el respaldo de los artesanos y trabajadores del textil del barrio de la Puebla ${ }^{50}$. Las dos parcialidades se presentan en la documentación con tintes religiosos pero, en realidad, reproducían las tensiones existentes entre mercaderes y tejedores, cuya rivalidad se acrecentaría en los años siguientes.

Don Sancho de Castila fue designado por don Alfonso como tenente de la ciudad con todos los poderes civiles y militares, lo que significaba en la práctica la suspensión de las atribuciones jurisdiccionales del obispo sobre la ciudad. Los palentinos quisieron dejar patente su ruptura con el señorío y su deseo de integrarse en el realengo con la destrucción de uno de los símbolos más característicos de su poder:

en tienpos de este obispo, don Gutierre IV, hubo grandes contiendas y diferencias entre él y los ciudadanos de Palencia, los cuales con licencia del infante don Alfonso, que se llamaba rey, derribaron por el suelo el alcázar y casa fuerte que los obispos tenían en la ciudad sobre el muro de la plaza vieja que se dezía del mercado viejo... ${ }^{51}$.

Las actas capitulares describen con precisión la forma y los medios utilizados por los vecinos para llevar a cabo sus propósitos:

Los de la çiibdat de Palencia por pregón público dado fueron todos con palos e azadones e palancas de fierro e otros pertrechos e carpinteros en que avía más de quinientos omes a derribar e començaron e derribaron el dicho alcáçar de la dicha çibdat e después los continuaron fasta lo acabar ${ }^{52}$.

La gravedad de los sucesos dio lugar a un largo pleito y, haciendo uso de sus poderes espirituales, el prelado decretó el entredicho apostólico sobre la ciudad durante un año. La represalia resultó especialmente cruel, porque la suspensión de los oficios religiosos coincidió con la terrible mortandad causada por una de las recurrentes epidemias de peste negra ${ }^{53}$.

Terminada la contienda, tras la muerte de don Alfonso en junio de 1468, la ciudad acató a Enrique IV. Don Sancho, que había liderado el apoyo de Pa-

50 ACHV, Sala de Hijosdalgo, 64, expd.1, 1566.

${ }^{51}$ FERNÁNDEZ DE MADRID, 1976: 311.

52 (ACP), Libro de Actas capitulares, fol. 156-156v.

${ }^{53}$ En aquellos dias se siguió en esta ciudad una muy cruel pestilencia, tanto que afirmaban morir en algún día hasta cien personas, y que en la mesma sepultura enterraban diez o doce cuerpos juntos, y la mayor lástima era ser en un tiempo de entredicho, que ni se tañian campanas por los difuntos, ni se decian misas ni exequias, y muy pocos se enterraban en sagrado..., FERNÁNDEZ DE MADRID, 1973: 194. 
lencia a la facción rebelde, fue encarcelado, lo que provocó un tumulto protagonizado por algunos caballeros que se oponían a la prisión de su lider políti$\mathrm{co}^{54}$. No obstante, apenas un año después, don Gutierre acordó el restablecimiento del orden y el fin de los litigios con don Sancho. Su protagonismo, sin embargo, no había finalizado. Su hijo, el canónigo don Pedro de Castilla, en ausencia del obispo, exhibió dos cartas reales en las que se nombraba a don Sancho asistente de la ciudad con autorización para proveer los oficios municipales de ese año. Ejerciendo ese cargo se mantuvo al frente de la ciudad hasta 1474, momento que fue cesado como tal, a pesar de la oposición de los palentinos ${ }^{55}$.

En 1473, con la llegada a la sede episcopal de don Diego Hurtado de Mendoza, se agravaron las tensiones por la falta de flexibilidad del obispo en el ejercicio de sus atribuciones. El momento más conflictivo surgió con una orden de Fernando de Aragón que mandaba recaudar alcabalas, impuesto que suponía una elevada carga fiscal entre los vecinos menos favorecidos, dado que la mayoría de los ciudadanos solventes estaban exentos de este tributo. En un intento de poner freno al desorden, el 15 de mayo de 1475 se convocó una asamblea general, en el convento de San Francisco, con el fin de averiguar:

quién o cuáles personas lo devían pagar porque muchos se escusan diciendo ser fijosdalgo e privillejados e por otras exenciones de escuderos, de cavalleros, que por quitar escándalos que serían bien de nombrar dos personas del estado de los caballeros e escuderos e fijosdalgo e otras dos de parte de los çibdadanos e pecheros para que estos, sobre juramento, determinasen e declarasen quáles personas debían gozar de la dicha esención de fijosdalgo ${ }^{56}$.

Los problemas fiscales se agravaron en los años siguientes por las constantes demandas de tributos reales extraordinarios. En 1476 los vecinos se vieron obligados a reunirse de nuevo en San Francisco porque muchos se escusavan disiendo ser fijosdalgo e privillejados e por otras exenciones de escuderos de caballos. En este caso, los asistentes decidieron nombrar a dos procuradores, uno del estamento de los caballeros y otro de los pecheros, para que determinasen e declarasen quales personas debian goçar de la dicha esención de fijosdlago y quales non ${ }^{57}$.

Los altercados con el obispo y el revuelo provocado por los impuestos continuaron durante el año siguiente, dando lugar a una nueva petición a la

54 VALLE CURIESES DEL, 2007: 31.

55 AMP, LAM, 5-3-1469.

56 AMP, LAM, 15-04-1474, Rafael del Valle calcula que, en esos momentos, sobre una población aproximada de 1.600 vecinos, equivalente a unos 6.700 habitantes, el $15 \%$ de la población estaba exenta: 500 habitantes pertenecían a la nobleza urbana y otros 500 eran excusados eclesiásticos. VALLE CURIESES DEL, 2007: 33-34.

${ }^{57}$ AMP, LAM, 15-09-1476, fol. 302, VALLE CURIESES DEL, 2007: 67. 
Corte del envío de un corregidor. La razón alegada por los procuradores de la ciudad era que Palencia estaba en perdición e por se perder por mengua de justicia porque non temen a los alcaldes della ${ }^{58}$. Pese a la oposición de un sector del concejo a la llegada de un nuevo corregidor, Alonso de Deza tomó posesión de su cargo el 31 de mayo de 1476. Durante su mandato, a los problemas políticos y sociales de la ciudad se añadió una pertinaz sequía, que arruinó las cosechas y se prolongó durante todo el año siguiente, provocando la hambruna en la ciudad. En aquel año, el desorden era tal que la corona tuvo que enviar dos pesquisidores, uno en febrero y otro en marzo, para intentar poner orden por las constantes peleas y heridos que se estaban produciendo entre los vecinos ${ }^{59}$.

En este contexto, el concejo reclamó a la Corona el derecho de nombramiento de los oficiales del concejo, mientras que el obispo alegaba las atribuciones jurisdiccionales de la Iglesia sobre Palencia. Los Reyes debían tomar posiciones ante un pleito que no podía posponerse, pero la solución no era fácil. Tanto la ciudad como su obispo, don Diego Hurtado de Mendoza, habían apoyado a Isabel en la lucha por el trono, y ambos esperaban como respuesta el respaldo de la Corona. Finalmente, la balanza se inclinó del lado del señorío episcopal; los Reyes Católicos confirmaron los privilegios, franquezas, libertades, exenciones e inmunidades otorgados por sus antepasados al obispo y al cabildo de Palencia ${ }^{60}$, pero la victoria para el señorío fue solo aparente. El creciente intervencionismo del poder real en las ciudades supuso en la práctica una merma de la autonomía municipal y, al mismo tiempo, debilitó la autoridad señorial provocando a la larga su declive.

Las protestas y disturbios constantes provocaron la presencia frecuente de delegados regíos hasta que, en 1483, acabó por institucionalizarse el corregimiento en la ciudad ${ }^{61}$. El 13 de diciembre de ese año, los Reyes nombraron corregidor al salmantino Francisco de Maldonado para finalizar la pesquisa, iniciada unos meses antes, por las desavenencias que mantenía el concejo con el obispo por el gobierno de la ciudad. Tras tomar posesión de su cargo, el nuevo corregidor suspendió a los alcaldes y al merino, nombrados por el obispo, y designó a sus propios oficiales. El prelado se resistió a aceptar la pérdida de poder que suponía la instauración del corregimiento, reivindicó los derechos del señorío en la Corte e incluso reclamó la restauración del alcázar. Tras una multitudinaria sesión convocada para esclarecer lo sucedido, a la que asistieron cientos de vecinos que no habían sido llamados, el concejo se

58 AMP, LAM, 19-05-1475, fol. 271.

59 VALLE CURIESES DEL, 2007: 70.

${ }^{60}$ VALLE CURIESES DEL, 2007: 85-87.

${ }^{61}$ GONZÁLEZ ALONSO, 1970. LUNELFELD, 1989. NARGANES QUIJANO, 64 (Palencia, 1993): 597-610. 
opuso rotundamente a la reconstrucción del alcázar y, frente a la restitución de los poderes del señorío, los alcaldes y regidores manifestaron que la ciudad debía ser del rey e non del señor obispo ni cabildo, postura que apoyarían junto con los vecinos y, si fuera preciso, con su vida y sus haciendas.

La reina envió de nuevo un pesquisidor a Palencia para restablecer el orden. Como primera medida se prohibieron las asambleas de vecinos y se estableció que solo los procuradores designados al efecto pudieran reunirse con el obispo para tratar sobre el pleito por el señorío. A la espera de una resolución definitiva en el pleito por el gobierno de la ciudad, el concejo intentó avanzar en su deseo de emancipación, solicitando a la Corte que fuera el corregidor, como representante de la Corona, quien se encargara de la provisión de los oficios municipales. Se trataba de una estrategia para conquistar la reivindicación secular del derecho del nombramiento de alcaldes y regidores, pero no dio resultado porque los Reyes confirmaron las atribuciones jurisdiccionales del obispo sobre el concejo.

La presencia permanente del corregidor no significó la autonomía jurisdiccional de la ciudad, pero en cambio proporcionó el marco para que los poderosos se consolidaran al frente del concejo. Con ese fin, los regidores se apresuraron a introducir algunas modificaciones en las ordenanzas municipales que dejaban el control del proceso electoral en manos de la clase dirigente, al limitar las atribuciones de la asamblea vecinal a la designación de la persona más principal del concejo, que debía iniciar el proceso electoral. En caso de que no hubiera consenso sobre quién debía ser esa persona, la elección se haría de acuerdo con el corregidor.

En las elecciones municipales de marzo de 1484, el obispo presentó una cédula real que ordenaba al corregidor seguir la costumbre antigua en la nominación de las alcaldías y regidurías ${ }^{62}$. Aquel año, paradójicamente, no hubo disturbios durante los comicios. Tal vez los palentinos se daban por satisfechos queriendo ver en la limitación del poder señorial por la corona una victoria propia, aunque no era más que el reflejo del signo de los tiempos: el proceso de centralización monárquico estaba ganando terreno frente a la autonomía de las ciudades.

\section{La lucha de bandos entre tejedores y mercaderes (1490-1520)}

En la última década del siglo XV y primeros años de la centuria siguiente se intensificó la presencia de caballeros al frente de las magistraturas locales, y la lucha por el poder político tuvo como principales protagonistas a los mercaderes y tejedores, lo que aportó al conflicto una connotación socioeco-

62 VALLE CUERIESES DEL, 2007: 103. 
nómica ${ }^{63}$. Los dos grupos se articularon en torno a las cofradías, convertidas en instrumentos de acción política ${ }^{64}$.

Como se demostró muy pronto, la reforma electoral, que dejaba el proceso en manos de la persona principal, posibilitó la manipulación de las candidaturas en favor de los grupos que se disputaban el poder e intensificó las luchas por el control del concejo:

agora de dos o tres años a esta parte algunas personas desa çibdat an partido e defraudado la dicha costunbre del dicho nombramiento tratando e aviendo maneras... quien será la una persona que a de nombrar las dichas dos personas... señalándolas asy mismo por nonbrar e quiénes será las dichas veinte personas... señaládolas asimismo por nombrar e quiénes serán las dichas sesenta personas para regidores e las otras personas para alcaldes... aviendo tales maneras commo el dicho nombramiento de las dichas personas e delas más dellas vaya conçertado e asentado antes de que se faga en público en el dicho conçejo ${ }^{65}$.

Los Reyes en 1486 enviaron una carta al obispo instándole a que sus provisores escogieran, de entre los candidatos propuestos por la ciudad, a los más ábiles e suficientes para los dichos oficios según se había dispuesto en años anteriores, en vez de elegir a los más afines al cabildo. Esta orden real no hace más que poner de manifiesto la nueva realidad imperante: la lucha por el poder político y económico se había desplazado de forma definitiva a los sectores más poderosos de la ciudad ${ }^{66}$. Las fuentes aluden a la formación de juntas y bandos en liza por el poder ${ }^{67}$, que contaban con el apoyo en unos casos del prelado y las jerarquías eclesiásticas, y en otros, de grandes nobles que tenían intereses económicos y jurisdiccionales en la comarca.

En 1486 tenemos noticias de la existencia de un grupo de caballeros, denominados los veinticinco, que celebraban ayuntamientos secretos, apoyados por el tesorero y regidor Pedro González de Madrid. En esta liga figuraban, entre otros, Diego Gómez, Ferrand González de Ávila, escribano, y Bartolo-

${ }^{63}$ Acerca de las élites urbanas y luchas de bandos: ASENJO-GONZÁLEZ, 28, (Durango, 2009c): 52-84. DÍAZ DE DURANA, 2002, XXIX: 81-1012. MONSALVO ANTÓN, 2009a, 3, 201-214. DÍAZ DE DURANA, 2002: 81-112.

${ }^{64}$ Como ha constatado Solórzano Telechea, las cofradías se convirtieron en las villas del Cantábrico en el marco organizativo del común para promover su participación en los gobiernos locales, SOLÓRZANO TELECHEA, 14, (2013): 239-257, sobre esta misma temática puede consultarse también: DIAZ DE DURANA Y FERNÁNDEZ LARREA, 14 (2013), 63-80.

${ }^{65}$ ESTEBAN RECIO, 2 (Palencia, 1987): 560.

${ }^{66}$ En la nómina de oficiales del concejo de los últimos años del siglo XV y principios de la centuria siguiente figuran regularmente mercaderes de origen converso, como los Rúa, los Bertavillo, García de las Casas etc. ESTEBAN RECIO, 1991: 1161.

${ }^{67}$ En este caso se trata de bandos-parcialidades no de los linajes, característicos de otras ciudades castellanas: MONSALVO ANTÓN, 2008: 159-209. 
mé Solórzano, cantero ${ }^{68}$; y aunque solicitaron a la Corte el derecho a realizar sus juntas, tras una primera respuesta afirmativa, finalmente fueron desautorizadas $^{69}$. No tenemos datos que avalen la hipótesis, pero es probable que este grupo nobiliario constituyera el núcleo que lideraba la familia de don Sancho de Castilla y sus descendientes, quienes según un documento del siglo XV han sido y son la prençipal parcialidad de la ciudad ${ }^{70}$.

A principios de los años 90 conocemos la existencia de dos bandos agrupados en cofradías ${ }^{71}$, que contaban con el apoyo de grandes del reino con sólidos intereses en Tierra de Campos. El enfrentamiento que mantenían en esos momentos el duque de Nájera, don Pedro Manrique - señor de Amusco y Paredes de Nava - y el condestable de Castilla, don Bernardino de Velasco ${ }^{72}$, se había extendido a la Ciudad del Carrión, capital de la Merindad de Campos. Los Reyes se apresuraron a dar órdenes para que cesaran las contiendas y prohibieron expresamente a los vecinos que acudieran al llamamiento de estos señores... so pena de muerte e perdimiento de sus bienes ${ }^{73}$. Pero los dos grandes del reino tenían vasallos y allegados en la ciudad, y en torno a ellos se crearon dos facciones claramente definidas: los mercaderes, apoyados por el Contestable de Castilla, y los tejedores, respaldados por el duque de Nájera. Con la fuerza que les proporcionaba el apoyo nobiliario, los dos bandos trataron de imponer sus candidaturas en el concejo: porque se teme e se recela que al tiempo de elegir e nombrar los oficiales de la dicha cibdad avrá algunos roydos e alborotos queriendo cada parcialidad que de su parte sean nombrados los dichos oficiales en lo cual nos seamos deservidos e la dicha cibdad reciba daño ${ }^{74}$.

La escalada de tensión llevó a los monarcas a intervenir para atajar un conflicto que amenazaba con estallar en las elecciones municipales de ese año. Para evitar la confrontación, en 1491 los Reyes decidieron que el corregidor interviniera directamente en la elección de la persona principal, y que los elegidos para desempeñar los cargos de alcaldes y regidores no sean de los que biven de bivienda continua ni por acostamiento con los dichos duque e

${ }^{68}$ Dos de ellos, Ferrando González de Ávila y Bartolomé Solórzano, figuran en la lista de oficiales de 1488 como regidores. ESTEBAN RECIO, 1990b: 597.

69 AMP, L.A.M. 29-1486, fol. 95, VALLE CUERIESES DEL, 2007: 114-115.

${ }^{70}$ ACP, arm. III, leg. 4, no 398.

${ }^{71}$ En torno el papel de las cofradías y los bandos en las luchas sociales puede consultarse, SOLÓRZANO TELLECHEA, 14 (Valladolid, 2013): 230-257.

${ }^{72} \mathrm{La}$ base de poder de los Velasco radicaba en Burgos, aunque se proyectaba sobre la Tierra de Campos MONTERO MÁLAGA, 2012. La obra de referencia sobre los Enríquez sigue siendo: MARTÍNEZ SOPENA, 1977.

73 AMP, LAM, 29-09-1490 y 3-12-1490, fol. 165. En relación a la presencia de la alta nobleza en las ciudades y la intervención en los gobiernos locales puede consultarse el trabajo de ASENJO-GONZÁLEZ, 21 (Salamanca, 1999):49-115.

74 AGS, RGS, Leg., 149005,207, 1490-5-14. 
don Bernaldino, ni de los que conellos o con qualquier dellos fizieron e dieron logar a confederaciones o parçialidades ${ }^{75}$. Esta nueva modificación del régimen electoral palentino institucionalizaba la intervención real en los comicios municipales, al tiempo que trataba de poner coto al intervencionismo de la alta nobleza en el gobierno de la ciudad.

Es un hecho que, tras la crisis del siglo XIV, se intensificó la intervención de la alta nobleza en los gobiernos municipales ${ }^{76}$, a través de procedimientos muy variados y, en muchos casos, ilegales; de ahí que el fenómeno haya sido calificado por José María Monsalvo como injerencias bastardas. Los Reyes Católicos dictaron medidas generales contra el intervencionismo nobiliario en las ciudades, que atentaba contra sus intereses centralizadores, al tiempo que avivaba las rivalidades entre las facciones locales. En 1492 llegaron a Palencia dos provisiones reales: en la primera, los Reyes ordenaban que ningún corregidor, alcalde, regidor u oficial del concejo, pudiera bivir con ningún prelado nin señor, so ciertas penas; en la segunda mandaban que los que hubieran convivido con caballeros más de seis años abandonaran su compañía y juraran no bivir con ellos ni levar tierra ni acostamiento público, ni secreto, ni directo ni indirecto, so pena de una cantidad de 30.000 maravedís y el destierro por el tiempo que fijaran las autoridades judiciales ${ }^{77}$. A raíz de este decreto, durante 1492 perdieron sus regidurías Juan Ortega (caballero), Juan Delgado (caballero/trapero), Alonso de Villegas (caballero) y Toribio Sánchez, todos ellos allegados del Condestable ${ }^{78}$.

Como se deduce de un pleito promovido en la Corte, en 1491, por los mercaderes traperos de la Cofradía del Santo Espíritu contra los tejedores de las Cofradías de la Trinidad y de Santa María del Ángel ${ }^{79}$, las rivalidades políti-

75 AGS, RGS, leg., 1491-02-236.

${ }^{76}$ En Europa, como ha señalado Máximo DIAGO, a diferencia de lo sucedido en las ciudades castellanas, la alta nobleza no interfirió en los gobiernos municipales. DIAGO HERNANDO, 37/2 (Madrid, 2007): 781-822. Respecto a la intervención de la alta nobleza en las ciudades: GUERRERO NAVARRETE, 2008: 241-279 y JARA FUENTE, 14 (Valladolid, 2013): 105-127.

77 AMP, LAM 26-11-1492, fol. 214. en VALLE CURIESES DEL, 2007: 161.

78 AMP, LAM 26-11-1492, fol. 214. La suspensión debió de ser temporal, ya que 1493 Juan Delgado aparece en las listas de oficiales del concejo desempeñando el cargo de regidor, ESTEBAN RECIO, Palencia, 1990: 598-599. En 1516 Alonso de la Vega, vecino y regidor de la ciudad, solicitó al corregidor su reinserción en el concejo, porque él y otros regidores habían dejado de vivir con el Condestable de Castilla. AGS, RGS, CP, Palencia, leg. 15.

${ }^{79}$ Los tejedores contaban en el siglo XV con una sólida organización gremial, cuyos precedentes se remontan a la segunda mitad del siglo XII. En 1197, Alfonso VIII tomó bajo su protección al menester de los tejedores de la Cofradía del Ángel, reconoció sus buenas costumbres y dotó a la institución de una serie de privilegios. En 1407 el gremio textil de Palencia recibió una de las primeras ordenanzas que se conocen en el reino. GONZÁLEZ MÍNGUEZ, 63 (Palencia, 1992): 95-123. 
cas tenían, además, un trasfondo económico ${ }^{80}$. Los mercaderes solicitaron al Rey la introducción de una serie de cambios en los estatutos de los tejedores, favorables a sus intereses. En última instancia, lo que pretendían era debilitar la estructura gremial, liberalizar la producción y hacerse con el control de proceso productivo ${ }^{81}$. Los tejedores, apoyados por los sectores populares y algunos oficiales del concejo pertenecientes a su parcialidad, defendieron con las armas su organización, competencias y privilegios, pero el pleito terminó resolviéndose a favor de los comerciantes de paños ${ }^{82}$.

En las décadas siguientes, la rivalidad entre mercaderes y tejedores y la influencia de la alta nobleza continuaron siendo una constante en la vida política palentina $^{83}$. La creciente intervención de la alta nobleza en las ciudades obligó a los monarcas a dictar leyes generales en contra del clientelismo de quienes ocupaban cargos municipales, prohibiendo expresamente que pudieran ser ejercidos por personas que mantuvieran vínculos de vasallaje con los grandes del reino ${ }^{84}$.

En los años que precedieron al estallido de la Guerra de las Comunidades, la ciudad reforzó la presión en la Corte para lograr la inserción en el realengo. Contra las pretensiones de la ciudad, el obispo se quejaba amargamente en la Corte de la pérdida progresiva de sus derechos y de la merma de su autoridad como consecuencia de la presencia del corregidor.

Los tres poderes presentes en la ciudad -el señorío, el concejo y la autoridad real- habían pasado por diversas circunstancias en cuanto a la relación de fuerzas, pero la balanza se decantó finalmente a favor de la Corona en detrimento del señorío episcopal y de la autonomía municipal. En el año 1500 Palencia estuvo a punto de emanciparse del obispo, a raíz de una disposición de Fernando el Católico. La razón que esgrimía el monarca para tomar esa trascendental decisión es que siendo como es (Palencia) cabeza de obispado e una de las principales que ay en Canpos non es cosa decente ni conveniente que esté apartada de la corona Real e puesta en señorío e subjeción de otra

${ }^{80}$ La coincidencia entre oligarquías políticas y élites económicas ha sido resaltada por: NARBONA VIZCAÍNO, 9 (Valencia, 1998): 105-126.

${ }^{81} \mathrm{El}$ conflicto de clase inherente entre el capital mercantil y la industria artesana a pequeña escala revela las contradicciones sociales de la sociedad urbana, ver HILTON (1988), 91-105; aunque los sectores más encumbrados del artesanado, en especial los tejedores, aprovecharon la presión popular para acceder al poder político local e integrarse en la clase dirigente.

82 AGS, RGS, 148709,205, 1487-9-20. El pleito se resolvió a favor de los mercaderes, según consta en: ARCHV, Registro de ejecutorias, caja, 36,1, 1491-3-30.

${ }^{83}$ En los comicios de año 1500, la elección de la persona principal, en la asamblea general del concejo, se realizó después de muchas pláticas e bozes. Finalmente, el elegido fue Juan de Bertavillo, del bando de los conversos. AMP, AM. Sesión extraordinaria, 3 -03-1500. AGS, CP, 1516, Madrid, 26 de septiembre.

${ }^{84}$ Un ejemplo concreto de intervención de la alta nobleza en el gobierno municipal a través del clientelismo nos lo ofrece JULAR PÉREZ-ALFARO, 53/185 (Madrid, 1993): 861-884. 
persona $^{85}$. Sin embargo, la integración de la ciudad en el dominio realengo no se llevó a efecto, como lo prueba el hecho de que los prelados siguieran en los años posteriores nombrando a los oficiales de concejo.

Por su parte, la clase popular, en medio de esta dialéctica de los grandes poderes, siguió luchando por garantizar su participación en el gobierno municipal a través de sus representantes oficiales: los procuradores de la ciudad ${ }^{86}$. A mediados del siglo $\mathrm{XV}$, la función era desempeñada por dos regidores pertenecientes al común, pero en 1447 los caballeros revindicaron la participación de su estamento en el cargo. En 1490 se introdujo en el ordenamiento municipal la norma de que la representación de la ciudad quedara en manos de los dos hombres buenos, uno del estamento de los caballeros y otro del estamento de los pecheros, designados por la asamblea general del concejo para iniciar el proceso electoral. La nueva normativa mantenía la representación estamental, pero arrebataba al regimiento la capacidad de designarlos y el cargo era asumido por personas que no formaban parte del concejo, lo que proporcionaba al cargo una mayor independencia ${ }^{87}$. A partir de ese momento, los procuradores de la ciudad se convirtieron en figuras incómodas tanto para la institución municipal como para el señorío episcopal.

Los sucesos acaecidos durante las elecciones municipales de 1510 demuestran, sin embargo, que el regimiento había vuelto a nombrar entre sus miembros a los procuradores de la ciudad. Ese año, los vecinos, ateniéndose a los derechos que recogía la normativa, eligieron directamente a dos procuradores que no pertenecían al regimiento. Como consecuencia de esta iniciativa popular, el prelado decretó el entredicho en la ciudad, lo que prueba al mismo tiempo la connivencia entre el concejo y el cabildo para apartar al común del gobierno municipal. Este atentado contra los derechos de la asamblea vecinal y la injusticia de las medidas represivas provocaron un levantamiento armado en el que, según las fuentes, participaron más de 4.000 vecinos. Los sublevados se dirigieron contra el poder señorial, pero quisieron simbolizar también su rechazo a la autoridad religiosa que representaba el obispo, obligando a un clérigo francés que se encontraba de paso en la ciudad a que dijera misa en medio de la plaza ${ }^{88}$.

${ }^{85}$ ACP, arm. III, leg., 4, no 397.

${ }^{86}$ Desde mediados del siglo XV, en las ciudades de la corona de Castilla se reforzó el protagonismo político de los sectores populares, como consecuencia de las reivindicaciones del común por conseguir una representación oficial en los concejos mediante la figura de los llamados procuradores mayores o procuradores del común. Sobre la organización de los pecheros para la defensa de sus intereses políticos: MOSALVO ANTÓN, 7 (Salamanca, 1987): 37-94.

${ }^{87}$ ESTEBAN RECIO, 1989: 75-76; 1992: 1158.

${ }^{88}$ ESTEBAN RECIO, 1992: 1162. 


\section{0-1521. La toma de poder por la clase popular: el concejo comunero}

Durante la Guerra de las Comunidades de $1520^{89}$ afloraron en Palencia todos los conflictos vividos en el último siglo ${ }^{90}$. La ciudad resucitó el viejo pleito sobre el derecho de elección de los cargos locales, pero, a medida que avanzaba el movimiento comunero, la población palentina se dividió en dos frentes: el bando radical estaba encabezado por algunas personalidades, como el chantre de la Iglesia Mayor y el licenciado Juan Martínez de la Torre, y agrupaba a artesanos y trabajadores de la ciudad ${ }^{91}$; y la facción de los moderados integraba a canónigos, hidalgos, rentistas y algún notable, como don Diego de Castilla. Ambos compartían intereses comunes, aunque las actuaciones más revolucionarias fueron obra exclusivamente de los radicales.

Las diferencias entre moderados y radicales o, lo que es lo mismo, entre la clase dirigente y los populares se hicieron visibles muy pronto. El 15 de marzo, nada más conocerse la noticia de la muerte del obispo, don Juan de Velasco, los regidores solicitaron al cabildo que dejara en manos de la ciudad el nombramiento de los oficiales del concejo, y designaron a Juan Fernández de Madrid, hermano del licenciado del Alcor, para que requiriera al Consejo Real que libertase a la ciudad del negocio de los oficios e dexara a los vecinos que los ficieren ${ }^{92}$.

Para canalizar la presión popular, que amenazaba con desbordar los cauces legales, don Diego, junto con algunos diputados, presentó ante el cardenal Adriano la reivindicación del derecho de la ciudad en la elección de los cargos, justificando la petición por la connivencia que existía entre los regidores y el prelado, a quien debían su nombramiento:

${ }^{89}$ La complejidad del movimiento comunero ha dado lugar a diferentes valoraciones e interpretaciones: Mientras J.A. Maravall y Joseph Pérez, calificaron el levantamiento como la primera revolución Moderna, J. Valdeón lo interpretó como la última revuelta medieval; el último eslabón de la reacción feudal iniciada con la crisis del siglo XIV; Gutiérrez Nieto, valoró en su estudio el carácter antiseñorial de la revuelta, mientras que Maravall destacaba el papel desempeñado por las clases medias burguesas En los últimos años se ha producido un revalorización del protagonismo de las clases populares, lo que ha llevado a DEL VAL VALDIVIESO 1996; 213-254, a considerar que el enfrentamiento entre la oligarquía y el común de las ciudades fue el eje del movimiento, una dimensión que ya había sido introducida por S. Haliczer. El fracaso de la protoburguesía que encabezó el movimiento, impidió su consolidación como clase. SÁNCHEZ LEÓN (1998) por su parte enfatiza la conexión entre la evolución de las relaciones de clase y los cambios producidos en la esfera política, como consecuencia de la implantación del Estado absolutista.

${ }^{90}$ Para un contexto general sobre las ciudades en el período pre-comunero: ASENJOGONZÁLEZ, 21 (Salamanca 1999): 49-115. DEL VAL VALDIVIESO, 26, 2011; 9-23.

${ }^{91}$ Entre los populares figuraban el tundidor Salazar, Juan el alabardero, el tejedor Tordesillas, Rodrigo el cabestrero, Bernal el cordonero, varios cerrajeros, cabestreros y boticarios. AGS, Consejo Real, leg. 79, fol.2, citado por GUTIÉRREZ NIETO, 1974: 152.

92 RODRÍGUEZ SALCEDO, 1953: 83. 
allegándome que muchas vezes tienen pleitos con el obispo, y así los regidores por él puestos no curan suficientemente de lo que toca a la autoridad de la çibdad y que más procuran congraciarse con el obispo del cual han alcanzado tal honra ${ }^{93}$.

Durante los primeros meses del conflicto, siguió funcionando en Palencia el regimiento elegido por el obispo, pero la ciudad nombró dos diputados por cada parroquia, que eran la más clara expresión de la ideología comunera y que, en la práctica, funcionaban como un gobierno paralelo, respaldado por el movimiento asambleario. A medida que se afianzaba el poder de la Junta y las ciudades creaban sus gobiernos populares, la facción radical fue imponiéndose al gobierno local y a la autoridad señorial. En julio llegó la noticia a Palencia de que la persona elegida para ocupar la mitra había sido don Francisco Ruiz de la Mota, brazo derecho de Carlos V, acusado de poco afecto al pueblo, y de que el cardenal había rechazado la demanda autonomista de la ciudad. La reacción llegó muy pronto y el 22 de agosto los vecinos, aprovechando el cambio de titularidad de la mitra, se sublevaron contra el señorío, depusieron a los cargos del concejo y eligieron, de entre las personas leales a la Comunidad, nuevos oficiales ${ }^{94}$ :

Como afirma Gutiérrez Nieto, este acontecimiento constituye un hito revolucionario que no se produce en otras ciudades comuneras. Es verdad que en todas ellas la Comunidad asume el poder local, pero lo hace mediante ayuntamientos extraordinarios que no representan una ruptura abierta con los antiguos $^{95}$. En Valladolid, por ejemplo, se constituyó una Junta en la que se integraban, junto a los diputados de las cuadrillas y algunos notables, varios regidores, pero no nombraron un regimiento nuevo ${ }^{96}$. En Palencia, sin embargo,

los comuneros hicieron otra novedad, que como el obispo siempre hace los regidores en principio de marzo, y según habemos dicho duran por un año, agora el pueblo en agosto quitó los regidores puestos por el obispo y hizo otros por su propia autoridad, los cuales gobernaron todo el tiempo que duraron las alteraciones. Los del pueblo quitaron las varas a la justicia y las dieron a personas de la comunidad e hicieron que su alcalde fuera también alcalde mayor del adelantamiento... Asimismo echaron de la ciudad a los provisores del obispo y no consintieron haber audiencia episcopal en ella, ni ellos se atrevieron a estar en la ciudad por temor del pueblo 97 .

El concejo comunero intentó consolidar las conquistas populares incorporando nuevos capítulos a las ordenanzas municipales, que recogían los deseos

\footnotetext{
93 RODRÍGUEZ SALCEDO, 1953: 101.

${ }^{94}$ RODRÍGUEZ SALCEDO, 1953: 91.

95 GUTIÉRREZ NIETO, 1974: 149.

${ }^{96}$ AGS, PR., 4-54 (Libro de Acuerdos de la Junta).

${ }^{97}$ FERNÁNDEZ DE MADRID, 1973: 406.
} 
del vecindario en cuanto a su intervención directa en el gobierno municipal ${ }^{98}$.

Poco después, a finales del verano, los palentinos expresaron su rechazo al señorío del obispo destruyendo uno de sus símbolos más emblemáticos ${ }^{99}$ :

\begin{abstract}
juntándose un día todo el pueblo a campana tañida, inducidos por algunos hombres revoltosos y amigos de escándalo, fueron con mano armada a Villamuriel, que es la casa y fortaleza del obispo, donde había muy buenos aposentamientos, y la quemaron toda, derribaron la mayor parte de la torre, y esto fue el 15 de septiembre de 1520; después talaron e destrozaron la mayor parte del soto del obispo, cerca de Villamuriel ${ }^{100}$.
\end{abstract}

En esos momentos, la ciudad, respaldada por el gobierno de la Comunidad, había logrado imponerse al señorío, pero todavía no formaba parte de la Junta. Desde Valladolid se apremiaba para que Palencia mostrara su apoyo a la Comunidad; sin embargo, los moderados, liderados por don Diego de Castilla, eran partidarios de que la ciudad se mantuviera en el bando realista. Finalmente, las gentes del común lograron imponerse en la asamblea celebrada el 22 de noviembre en San Francisco, y Palencia se decantó oficialmente por el bando rebelde. En el cabildo, aunque los capitulares seguían fieles a los virreyes, varios canónigos y beneficiados se inclinaron por los comuneros ${ }^{101}$.

La obediencia a la Junta se estableció de forma pacífica. Gonzalo de Ayora fue nombrado consejero militar y justicia de Palencia, y don Diego de Castilla capitán general. Pero con la llegada del obispo Acuña a la urbe del Carrión el conflicto se radicalizó, y don Diego, ante el temor a ser apresado, huyó de la ciudad. En su lugar, la Junta nombró capitán general y gobernador de Palencia a Juan de Mendoza, hijo del cardenal Pedro González de Mendoza, que llegó con 500 hombres de armas y artillería. A pesar de que la ciudad estaba cada vez más agobiada por los impuestos solicitados por la Junta, Palencia siguió prestando su apoyo económico y militar a la Comunidad hasta el final de la guerra el 23 de abril de $1521^{102}$.

La victoria realista implicó el aplastamiento de los populares. En la lista de los exceptuados del perdón se incluyó a algún personaje destacado, como Gonzalo de Ayora, a tres notarios, un canónigo, un jurista y un boticario, pero la mayor parte de los condenados fueron pequeños comerciantes, artesanos y obreros del textil. Al fin y al cabo, como nos refiere un testigo de los aconte-

98 RODRÍGUEZ SALCEDO, 1953: 130.

${ }^{99}$ Santiago Valvo, regidor, dijo a Pedro Álvarez que se habia de derribar la dicha fortaleza porque hera casa de ladrones, GUTIÉRREZ NIETO, 1974: 150.

100 RODRÍGUEZ SALCEDO, 1953: 130.

101 GUTIÉRREZ NIETO, 1974: 168.

102 FERNÁNDEZ MARTÍN, 1980-1981. 
cimientos, la mayoría alcanzada por el bando comunero en la ciudad se debía a que la mayor parte della era gente de mediana condición e la otra gente pobre e baxa, e ay pocos caballeros ${ }^{103}$.

La Iglesia recobró sus atribuciones, pero el señorío episcopal estaba ya herido de muerte. Durante el reinado de Felipe II, Palencia se integró definitivamente en el realengo, aunque la liberación del señorío trajo consigo la consolidación de la oligarquía local ${ }^{104}$. Con la venta de las regidurías, la aristocracia palentina hizo realidad su secular aspiración a monopolizar el poder municipal e incorporar a sus patrimonios los cargos locales. Después de siglos de lucha, la urbe del Carrión logró equipararse a las demás ciudades, pero lo consiguió cuando las libertades municipales habían sido cercenadas definitivamente por la Corona.

\section{CONCLUSIONES}

La historia de Palencia en la Baja Edad Media está marcada por la influencia del señorío episcopal, que dominaba la ciudad desde el momento de su restauración en las primeras décadas del siglo XI. Los obispos, como señores de la urbe, tenían privilegios, monopolios y atribuciones jurisdiccionales sobre la vida económica y social de los palentinos y, en especial, sobre el concejo y el nombramiento de los cargos locales. Asimismo, como titulares de la sede episcopal, ejercían su autoridad sobre la vida religiosa de los feligreses, un poder que, como hemos visto, les proporcionaba medios excepcionales de carácter represivo contra la insumisión de los vecinos.

La ciudad nunca aceptó de buen grado tal concentración de poder en manos del señorío y la jerarquía eclesiástica. De hecho, la conflictividad social y la violencia de las revueltas de finales de la Edad Media en Palencia tienen como trasfondo la reivindicación de la autonomía municipal, compartida a lo largo de tres siglos por la gran mayoría de los palentinos, como medio para liberarse del señorío y acceder al régimen del realengo.

Aquella reivindicación secular continuó siendo el denominador común de la conflictividad social de Palencia a lo largo del siglo que transcurre entre la revuelta de 1421 y la revolución comunera de 1521 . Pero en esos cien años apare-

103 GUTIÉRREZ NIETO, 1974: 152.

${ }^{104}$ El fracaso de las Comunidades no supuso la pérdida de las libertades municipales, como planteaba la historiografía del siglo XIX, ya que desde el siglo XIV se asiste a una progresiva intervención del poder real en las ciudades con la consiguiente merma de la autonomía municipal. Pero en la Guerra de las Comunidades, las ciudades revindicaron un papel político en el gobierno del Reino y la clase popular luchó por la democratización de los gobiernos locales. 
cen algunos hechos y circunstancias distintivas, que hacen especialmente interesante el estudio de la singularidad del tránsito de Palencia a la Edad Moderna:

El señorío episcopal evolucionó desde su auge en las primeras décadas del siglo XV hacia su declive progresivo y su desaparición durante el reinado de Felipe II, en que la ciudad se integró definitivamente en el realengo.

El declive del señorío en este periodo se debe, sobre todo, a tres factores:

a) El protagonismo del común, en lucha no solo contra el poder eclesiástico que dominaba jurisdiccionalmente la ciudad, sino también contra la clase dirigente local que pretendía monopolizar el concejo. El protagonismo del común culminó, durante la Guerra de las Comunidades, con la toma de poder de la ciudad, la destitución de los cargos locales y la creación de un concejo comunero elegido por los vecinos, hecho que no se produjo en ninguna otra ciudad durante los dos años que duró la contienda.

b) El creciente intervencionismo de la Corona, que progresa desde su papel arbitral en el pleito por el realengo y los conflictos entre la ciudad y el señorío hasta la presencia permanente del corregidor, con la consiguiente merma del poder episcopal, cuyo declive es inversamente proporcional al incremento de la autoridad regia y de la política centralizadora de la monarquía.

c) La tendencia hacia la oligarquización del concejo por parte de la aristocracia local lleva a primer plano, desde la segunda mitad del siglo XV, la lucha por el poder de los grupos sociales más enriquecidos, que tratan de copar las magistraturas locales en perjuicio del común y acaban por perpetuarse en el poder con la desaparición del señorío.

Otro factor distintivo de la urbe palentina era la permeabilidad de su pirámide social, debida a las difusas líneas divisorias entre caballeros y acaudalados del común y entre estos y los pecheros enriquecidos. Todos ellos hicieron fortuna, en mayor o menor medida, a través de la actividad textil. Pero, junto al progreso económico, su promoción social se basaba, asimismo, en las relaciones de intereses con la jerarquía eclesiástica, de quien dependía en muchas ocasiones su acceso a la caballería local y sobre todo su presencia en los órganos de poder local, ya que era el obispo quien nombraba a los cargos del concejo entre la lista de candidatos propuestos por la ciudad.

Tradicionalmente, la política episcopal consistía en repartir los cargos locales entre caballeros, acaudalados y pecheros enriquecidos, con el fin de impedir la oligarquización del concejo y evitar que el gobierno de la ciudad se convirtiera en un contrapoder del señorío, dado que la normativa establecía la elección anual de los cargos municipales y que estos recayeran exclusivamente entre los vecinos de la ciudad. Pero el clientelismo y las relaciones de intereses entre los obispos y la élite civil y la eclesiástica corrompieron una y 
otra vez el proceso electoral en perjuicio de la clase popular, de forma que la mayoría o incluso la totalidad de los cargos locales acababan por actuar en favor del señorío y de sus propios intereses más que al servicio de la ciudad.

Los cambios más notables en el régimen electoral, conseguidos por las revueltas del común, se alcanzaron cuando la clase popular consiguió articularse en una organización poderosa, como la cofradía del Cuerpo de Dios, desde la que pudieron canalizar sus reivindicaciones sociales y políticas. A la postre, los mecanismos organizativos del común fueron desarticulados y prohibidos o por el señorío o por la Corona, pero la clase popular buscó otros cauces de presión, como la convocatoria de asambleas abiertas, que se demostraron sumamente eficaces, especialmente durante la Guerra de la Comunidades. Los principales beneficiarios de la lucha del común por impedir el cierre oligárquico del concejo fueron los sectores más enriquecidos de la población pechera. A través de la presión popular la élite del común consiguió en numerosas ocasiones acceder al poder local e insertarse en la clase dirigente, aunque en otras ocasiones llegó a provocar el desplazamiento de la oligarquía local, como sucedió en la revuelta comunera que desembocó en la toma de poder de la ciudad.

A partir del último tercio del siglo $\mathrm{XV}$, y aún más con la presencia permanente del corregidor en Palencia, fueron los ricos mercaderes y los tejedores quienes se disputaron los cargos locales. El conflicto revela las contradicciones existentes entre la clase mercantil y el artesanado gremial, en el que se agrupaba el grueso la clase trabajadora de Palencia, aunque a su cabeza figurasen los tejedores, es decir, la élite socio-profesional del gremio del textil. En el enfrentamiento, además del reparto de los cargos del gobierno municipal, lo que estaba en juego era la pervivencia de la organización gremial y su independencia frente a la pretensión de los mercaderes de hacerse con el control del proceso productivo. En medio de esa dialéctica, el poder real intervino para impedir la clientelización de la aristocracia local por la alta nobleza, rechazó las reivindicaciones populares, y mantuvo, aunque fuera formalmente, los privilegios del señorío.

Si a lo largo del siglo XV la ciudad se quejaba de los privilegios del señorío y el común se rebelaba contra los abusos de su autoridad, en los años anteriores a la Guerra de las Comunidades era el obispo quien se quejaba a la Corona por la merma de su poder como consecuencia de la presencia permanente del corregidor.

Por último, cuando estalla la rebelión comunera, la clase popular palentina, marginada del concejo por la oligarquía, aún bajo el yugo del obispo y cabildo, y esquilmada por las cargas fiscales del señorío, del concejo y de la Corona, se alzó en armas contra las tres instituciones, tomó el poder de la ciudad y reguló la intervención directa de los vecinos en el concejo comunero. Para lograr este éxito sin precedentes, el común fue capaz de formular sus reivin- 
dicaciones sociales y políticas, contó con sus propios líderes, muchos pertenecientes a la élite pechera, y con sus sistemas organizativos, principalmente las asambleas abiertas.

Aquel triunfo de la clase popular que, por fin, conseguía hacer realidad sus reivindicaciones, acabaría con la derrota de los comuneros en Villalar, el 23 de abril de 1521. Paradójicamente, cuando Palencia vio cumplida su reivindicación secular de convertirse en ciudad de realengo, las libertades municipales ya habían sido liquidadas por el centralismo de la Corona y la inserción en el realengo fue la llave que permitió a la aristocracia local hacerse por fin con el monopolio del gobierno local.

\section{Biblografía}

Asenjo-González, María, «Clientélisme et ascension sociale à Ségovie à la fin du Moyen Age», Journal of Medieval History, 12 (Southampton, 1986): 167-182.

Asenjo-González, María, «Las ciudades castellanas al inicio del reinado de Carlos V》 Studia Historica. Historia Moderna, 21 (Salamanca 1999): 49-115.

Asenjo-González, María, «El pueblo urbano: el "común”», en Ladero Quesada, Miguel Ángel (ed.), El mundo social de Isabel la Católica. La sociedad castellana a finales del siglo $X V$, Comité Español de Ciencias Históricas, Madrid, Dykinson, 2004; 181-194.

Asenjo González, María, «La aristocratización política en Castilla y el proceso de participación urbana» en Nieto Soria, José Manuel (ed.), La monarquía como conflicto en la Corona castellano-leonesa (c. 1230-1504), Madrid, Sílex, 2006; 133-196.

Asenjo-González, María (ed.), Oligarchy and patronage in Late Medieval Spanish Urban Society, Thurnhout, Brepols, 2009a.

Asenjo-González, María, «La aportación del sistema urbano a la gobernabilidad del Reino de Castilla durante la época de los Reyes Católicos (1474-1504)», Anuario de Estudios Medievales, 39/1 (Barcelona, 2009b): 307-328.

Asenjo-González, María, «Acerca de los linajes urbanos y su conflictividad en las ciudades castellanas a fines de la Edad Media», Clio y Crímen, 6 (Durango, 2009c): 52-84.

Barros, Carlos, Mentalidad justiciera de los Irmandiños, siglo $X V$, Madrid, Siglo XXI, 1990.

Beceiro Pita, Isabel, La rebelión irmandiña, Madrid, Akal, 1977.

Bonachía Hernando, Juan Antonio y Martín Cea, Juan Carlos, «Oligarquías y poderes concejiles en la Castilla Bajomedieval: balance y perspectivas», Revista d'historia medieval, 9, (Córdoba, 1998): 17-40.

Cabeza Rodríguez, Antonio, «Grupos de excluidos y formas de asimilación y reproducción social. El ejemplo de la catedral de Palencia en la época moderna» en Juan Hernández Franco (coord.), Familia y poder. Sistemas de reproducción social en España (Siglos XVI-XVIII), Murcia, Editum, 1995; 101-125. 
Carlé, Ma del Carmen y Fauve, María E.G de, (et al.) (eds.), La sociedad hispanomedieval: las ciudades, Barcelona, Gedisa, 2001.

Castillo, Santiago y Ortíz de Oruño, José María, Estado, protesta y movimientos sociales (coords.), Zarauz, Universidad del País Vasco, 1998.

Del Val Valdivieso, $M^{a}$ Isabel, «Ascenso social y lucha por el poder en las ciudades castellanas del siglo XV» En la España Medieval, 17 (Madrid, 1994): 157-184.

Del Val Valdivieso, $\mathbf{M}^{\mathrm{a}}$ Isabel, «Indicios de una clase en formación: el ejemplo de Medina del Campo a fines del siglo XV», Anales de la Universidad de Alicante. Historia Medieval, 7, (Alicante, 1988-1989); 193-224.

Del Val Valdivieso, $\mathrm{M}^{\mathrm{a}}$ Isabel, «Oligarquía versus “común”. Consecuencias sociopolíticas del triunfo del regimiento en las ciudades castellanas», Medievalismo 4 (Madrid, 1994); 41-58.

Del Val Valdivieso, $\mathrm{M}^{\mathrm{a}}$ Isabel, «Aspiraciones y actitudes socio-políticas. Una aproximación a la sociedad urbana de la Castilla bajomedieval», Juan Antonio, Bonachía Hernando (coord.), La ciudad. Aspectos de la vida urbana en la Castilla bajomedieval, Valladolid, Universidad de Valladolid, 1996; 213-254.

Del Val Valdivieso, $\mathrm{M}^{\mathrm{a}}$ Isabel, "Ciudades y villas castellanas en el contexto previo a la Guerra de las Comunidades», en Biblioteca 26: Estudio e investigación. El siglo XVI en la Ribera del Duero Oriental. Arte, Historia y Patrimonio, Aranda, Ayuntamiento de Aranda de Duero, 2011; 9-23.

Del Val Valdivieso, $\mathrm{M}^{\mathrm{a}}$ Isabel, «Conflictividad social en la Castilla del siglo XV», en Acta historica et archeologica medievalia, 26, (Valladolid, 2005): 1033-1050.

Del Val Valdivieso, $M^{\mathrm{a}}$. Isabel, «La identidad urbana al final de la Edad Media», en Anales de historia medieval de la Europa Atlántica, 1, (Santander, 2006): 5-28.

Diago Hernando, Máximo, «La participación de la nobleza en el gobierno de las ciudades europeas bajomedievales Análisis comparativo» Anuario de Estudios Medievales, 37/2 (Madrid, 2007):781-822.

Diago Hernando, Máximo, «El reforzamiento de los vínculos comunitarios a través de la fiesta en las ciudades castellanas en el marco de las cuadrillas y cofradías. Siglos XV-XVII», Revista de dialectología y tradiciones populares, 68/1, (Madrid, 2013): 33-56.

Díaz de Durana, José Ramón, «Las luchas de bandos: ligas nobiliarias y enfrentamientos banderizos en el nordeste de la corona de Castilla», en José Ignacio Iglesia Duarte (ed.), Las sociedades urbanas en la España Medieval: XXIX Semana de Estudios Medievales, Pamplona, Gobierno de Navarra, Educación y Cultura, 2002; 81-112.

Díaz de Durana, José Ramón y Fernández Larrea, Jon Andoni, «Acceso al poder y discurso político en la villas cantábricas al final de la Edad Media», Edad Media, Revista de Historia, 14 (2013) 63-80.

Esteban Recio, Asunción, Las ciudades castellanas en tiempo de Enrique IV: estructura social y conflictos, Valladolid, Universidad de Valladolid, 1985. 
Esteban Recio, Asunción, «Elecciones concejiles en Palencia a fines de la Edad Media: La pugna entre el obispo y la ciudad» en Actas del I Congreso de Historia de Palencia, Vol. 2, Palencia, Diputación Provincial de Palencia, 1987: 553-562.

Esteban Recio, Asunción, Palencia a fines de la Edad Media. Una ciudad de señorío episcopal, Valladolid, Universidad de Valladolid, 1989.

Esteban Recio, Asunción, «La lucha por el poder político en Palencia: el común en el gobierno municipal», en María Valentina Calleja González (coord.), Actas del II Congreso de Historia de Palencia, 2, Palencia, Diputación Provincial de Palencia, 1990; 569-599.

Esteban Recio, Asunción, «Sociedad y gobierno en una ciudad de señorío episcopal. Las raíces del movimiento comunero en Palencia», en Actas de las III Jornadas hispano-portuguesas de Historia Medieval. La Península en la era de los descubrimientos, Sevilla, Consejería de Cultura, 1992; 1157-1164.

Esteban Recio, Asunción e Izquierdo García, Ma Jesús, «Familias “burguesas” representativas de la élite palentina a fines de la Edad Media», Studia Histórica, Edad Media, X, (Salamanca, 1992): 111-146.

Estepa Díez, Carlos «La ciudad medieval: centro de poder, confluencia de poderes», en Beatriz Arizagaga Bolomburu y Jesús Ángel Solórzano Telechea, (eds.), La gobernanza de la ciudad europea en la baja Edad Media, Logroño, Instituto de Estudios Riojanos, 2011; 75-95.

Fernández de Madrid, Alonso, Silva Palentina, Palencia, Diputación Provincial, 1973.

Fernández Martín, Luis, «El movimiento comunero en tierras palentinas», Palencia en la Historia, Palencia, Caja Palencia, 1980-1981.

Freedman, Paul, «La resistencia campesina y la historiografía de la Europa medieval», Edad Media. Revista de Historia, 3. 2000, 17-37.

Fontana, Josep, Historia: análisis del pasado y proyecto social, Barcelona, Crítica, 1982.

Fuente Pérez, M $\mathrm{M}^{\mathrm{a}}$ Jesús, La ciudad de Palencia en el siglo XV. Aportación al estudio de las ciudades castellanas en la Baja Edad Media, Madrid, Universidad Complutense, 1989.

González Alonso, Benjamín, El corregidor castellano (1348-1808), Madrid, Instituto de Estudios Administrativos, 1970.

González Alonso, Benjamín, Sobre el estado y la administración de la Corona de Castilla durante el Antiguo Régimen, Madrid, Siglo XXI, 1982.

González Arce, José Damián, Gremios y cofradías en los reinos medievales de León y Castilla. Siglos XII-XV, Palencia, Región, 2009.

González Mínguez, César, «Los tejedores de Palencia durante la Edad Media», Palencia, Publicaciones de la Institución Tello Téllez de Meneses, 63, 1992; 95-123.

Guerrero Navarrete, Yolanda, «Rey, nobleza y élites urbanas en Burgos (siglo XV)», François Foronda y Ana Isabel Carrasco Manchado (dirs.), El contrato político en la Corona de Castilla. Cultura y sociedad politica entre los siglos X al XVI, Madrid, Dykinson, 2008: 241-279.

Guha, Ranajit, Las voces de la historia y otros estudios subalternos, Barcelona, Crítica, 2002. 
Gutiérrez Nieto, José Ignacio, Las Comunidades como movimiento antiseñorial, Barcelona, Planeta, 1973.

Hernández García, Ricardo, La industria textil de Palencia durante los siglos XVI y XVII: la implicación de una ciudad con la actividad manufacturera, Valladolid, Universidad de Valladolid, 2007.

Hilton, Rodney, Siervos liberados. Los movimientos campesinos medievales y el levantamiento inglés de 1381, Madrid, Siglo XXI, 1978.

Hilton, Rodney, «Las ciudades en la sociedad feudal inglesa», Conflicto de clases y crisis del feudalismo, Barcelona, 1988: 91-105.

Hobsbawm, Eric, Rebeldes primitivos. Estudio sobre las formas arcaicas de los movimientos sociales en los siglos XIXY XX, Barcelona, Ariel, 1968.

Iglesia Duarte, José Ignacio de la y Martín Rodríguez, José Luis, (coord.), Los espacios del poder en la España Medieval, XII Semana de Estudios Medievales, Nájera, Instituto de Estudios Riojanos, 2002.

Iglesia Duarte, José Ignacio (coord.), Conflictos sociales, políticos e intelectuales en la España de los siglos XIV y XV, 14, Semana de Estudios Medievales, Instituto de Estudios Riojanos, Nájera, 2003.

Jara Fuente, José Antonio, «Çercada de muchos contrarios. Didáctica de las relaciones políticas ciudad-nobleza en la Cuenca del siglo XV», Edad Media, Revista de Historia, 14 (Valladolid, 2013): 105-127.

Jara Fuente, José Antonio, «Vecindad y parentesco. El lenguaje de las relaciones políticas en la Castilla urbana del siglo XV», en François Foronda y Ana Isabel Carrasco Manchado, (dirs.) El contrato político en la Corona de Castilla. Cultura y sociedad política entre los siglos X al XVI, Madrid, Dykinson, 2008; 211-240.

Jular Pérez-Alfaro, Cristina, «La participación de un noble en el poder local a través de su clientela: un ejemplo concreto de fines del siglo XIV» Hispania, 53/185 (Madrid, 1993): 861-884.

Kula, Witold, Problemas y métodos de la historia económica, Península, Barcelona 1974.

Liddy Durham, Christian, Bishopric of Durham, Woodbridge, Boydell Press, 2008.

Lorenzo Cadarso, Pedro, Los conflictos populares en Castilla (siglos XVI y XVII), Siglo XXI, Madrid 1996.

Lorenzo Cadarso, Pedro, «Principales teorías sobre el conflicto social», Norba. Revista de Historia, 15 (Cáceres, 2001): 237-253.

Lunefeld, Marvin, Los corregidores de Isabel la Católica, Barcelona, Labor, 1989.

Macek, Joseph, La revolución husita: orígenes, desarrollo y consecuencias, Madrid, Siglo XXI, 1975.

Maravall, José Antonio, Las Comunidades de Castilla. Una primera revolución moderna, Madrid, Revista de Occidente, 1963.

Mollat, Michel y Wolff, Philippe, Uñas azules, Jacques y Ciompi. Las revoluciones populares en Europa en los siglos XIV y XV, Madrid, Siglo XXI, 1970. 
Monsalvo Antón, José Ma $\mathrm{M}^{\mathrm{a}}$ «La participación política de los pecheros en los municipios castellanos en la Baja Edad Media. Aspectos organizativos», Studia Histórica, Historia Medieval, 7 (Salamanca, 1987): 37-94.

Monsalvo Antón, José María, Teoría y evolución de un conflicto social: El antisemitismo en la Corona de Castilla en la Baja Edad Media, Madrid, Siglo XXI, 1985.

Monsalvo Antón, José María, «La sociedad política en las concejos castellanos de la Meseta durante la época del regimiento medieval. La distribución social del poder, en Concejos y ciudades en la Edad Media hispánica II Congreso de Estudios Medievales, León, Fundación Sánchez-Albornoz, 1990; 358-413.

Monsalvo Antón, José María, «Ayuntados a Concejo: acerca del componente comunitario en los poderes locales castellano-leoneses durante la Edad Media» en Flocel Sabaté, Joan Farré, (coords.), El poder a l'Edat Mitjana: Reunió científica, VIII Curs d'Estiu Comtat d'Urgell, Lérida, Pagès, 2004; 209-292.

Monsalvo Antón, José María, «En torno a la cultura contractual de las élites urbanas: pactos y compromisos políticos (linajes y bandos de Salamanca, Ciudad Rodrigo y Alba de Tormes)», El contrato político de la Corona de Castilla. Cultura y sociedad politica entre los siglos X-XVI, Madrid, 2008, 159-209.

Monsalvo Antón, José María, «Luchas de bandos en Ciudad Rodrigo durante la época Trastámara», en $\mathrm{M}^{\mathrm{a}}$ Isabel del Val Valdivieso y Pascual Martínez Sopena (coord.) Castilla y el mundo feudal: homenaje al profesor Julio Valdeón, 3, Valladolid, Universidad de Valladolid, 2009a; 201-214.

Monsalvo Antón, José María, «Violence between factions in Medieval Salamanca: some problems of Interpretation», Imago Temporis. Medium Aevum, 3, (Lérida, 2009b): 139-170.

Monsalvo Antón, José María, «Torres, tierras, linajes. Mentalidad social de los caballeros urbanos y de la élite dirigente en la Salamanca Medieval, siglos XIII-XV» en José María Monsalvo Antón (ed.), Sociedades urbanas y culturas politicas en la Baja Edad Media castellana, Salamanca, Universidad de Salamanca, 2013: 165-230.

Montero Málaga, Alicia, El linaje de los Velasco y la ciudad de Burgos (1379-1474). Identidad y poder político, Madrid, Marcial Pons, 2012.

Moreta, Salustiano, Malhechores-feudales. Violencia, Antagonismos y alianzas de clases en Castilla, siglos XIII-XIV, Madrid, Cátedra, 1978.

Mullet, Michael, La cultura popular y la protesta popular en la Europa durante la Baja Edad Media y la Edad Moderna, Barcelona, Crítica, 1990.

Muñoz Solla, Ricardo, «Judeoconversos burgaleses a fines de la Edad Media», Espacio, Tiempo y Forma, Serie III: $H^{a}$ Medieval, 22 (Madrid, 2009): 207-227.

Narbona Vizcaíno, Rafael, «Oligarquías políticas y elites económicas en las ciudades bajomedievales (siglos XIV y XV)», Revista d'Historia Medieval, 9 (Valencia, 1998): 105-126.

Narbona Vizcaíno, Rafael, «Vida pública y conflictividad urbana en los reinos hispánicos (siglos XIV-XV)», en José Ignacio Iglesia Duarte (ed.), Las sociedades ur- 
banas en la España Medieval: XXIX Semana de Estudios Medievales, Pamplona, 2002; 541-589.

Narganes Quijano, Faustino, «Acerca de los primeros corregidores en Palencia (ss. XV-XVI», Institución Tello Téllez de Meneses, 64 (Palencia, 1993): 597-610.

Nieto Soria, José Manuel, «Las relaciones monarquía-episcopado en Castilla, siglos XIII y XIV: definición de sus caracteres e interpretación de conjunto», en El pasado histórico de Castilla y León, I (Valladolid, 1983): 285-294.

Nieto Soria, José Manuel, «La relación de poderes en un señorío eclesiástico de ámbito urbano. Palencia (1280-1305)», En la España Medieval, 6 (Madrid, 1985): 625-640.

Nieto Soria, José Manuel, «Más que palabras: los instrumentos de lucha política en la Castilla bajomedieval» en José Ignacio Iglesia Duarte (ed.), Conflictos sociales, políticos e intelectuales en la España de los siglos XIV y XV, XIV Semana de Estudios Medievales, Logroño, Instituto de Estudios Riojanos, 2004; 165-204.

Oliva Herrer, Hipólito Rafael, «La industria textil en Tierra de Campos a fines de la Edad Media», Studia Histórica. Historia medieval, 18/19 (Salamanca 20002001): 225-251.

Oliva Herrer, Hipólito Rafael, «Conflictos antiseñoriales en el Reino de Castilla a fines de la Edad Media: viejas preguntas, ¿nuevas respuestas?», Historia. Instituciones. Documentos, 36 (Sevilla 2006), 313-331.

Oliva Herrer, Hipólito Rafael, «La prisión del rey»: voces subalternas e indicios de la existencia de una identidad política en la Castilla del siglo XV", Hispania, 71/238 (Madrid 2011): 363-388.

Ortiz Real, Javier, Cantabria en el siglo XV. Aproximaciones al estudio de los conflictos sociales, Santander, Tantin, 1985.

Pastor, Reyna, Conflictos sociales y estancamiento en la España medieval, Barcelona, Ariel, 1973.

Peinado Santaella, José Ángel, «La oligarquía municipal de Granada en los albores del dominio castellano», Edad Media, Revista de Historia, 14 (Valladolid, 2013): 213-237.

Pérez, Joseph, La revolución de las Comunidades de Castilla: 1520-1521, Madrid, Siglos XXI, 1977.

Pérez Ledesma, Manuel, «Cuando lleguen los días del cólera (Movimientos sociales, teoría e historia), Sánchez Nistal, José María, Montanari, Massimo et. al., Problemas actuales de la Historia. Terceras Jornadas de Estudios Históricos, Salamanca, Ediciones de la Universidad, 1993, 141-189.

Porshnev, Boris, Los levantamientos populares en Francia en el siglo XVII, Madrid, Siglo XXI, 1978.

Rodríguez Salcedo, Severiano, «Historia de las Comunidades Palentinas», Institución Tello Téllez de Meneses, $\mathrm{n}^{\circ} 10$ extraordinario, (Palencia 1953): 75-272.

Rubinstein, Juan Carlos, ;Viva el Común! Buenos Aires, Prometeo Libros, 2005.

Rudé, George, La multitud en la historia. Estudio de los disturbios populares en Francia e Inglaterra, Buenos Aires, Siglo XXI, 1971. 
Ruíz de la Peña Solar, Juan Ignacio, «Las ciudades de señorío eclesiástico y los conflictos por el control del gobierno local (1252-1350)», José Ignacio Iglesia Duarte, Conflictos sociales, políticos e intelectuales en la España de los siglos XIV y $X V$, XIV Semana de Estudios Medievales, Logroño, Instituto de Estudios Riojanos, 2004; 113-146.

Sánchez León, Pablo, Absolutismo y comunidad. Los orígenes sociales de la guerra de los comuneros en Castilla, Madrid, Siglo XXI, 1998.

Sarasa Sánchez, Esteban, Sociedad y conflictos sociales en Aragón. S. XIII al XV, Madrid, Siglo XXI, 1981.

Solórzano Tellechea, Jesús Ángel, «Commo uno más del pueblo: Acción colectiva y ambiciones políticas del común en las villas portuarias de Cantabria en la Baja Edad Media», Edad Media. Revista de Historia, 14 (Valladolid, 2013): 239-257.

Tena García, Soledad, «Cofradías y concejos: encuentros y desencuentros en San Sebastián a fines del siglo XV», José María Monsalvo Antón (ed.), Sociedades urbanas y culturas políticas en la Baja Edad Media Castellana, Salamanca, Ediciones Universidad, 2013; 231-254.

Thompson, Edward P., La formación de la clase obrera en Inglaterra, Barcelona, Crítica, 1989.

Thompson, Edward P., Miseria de la teoría, Barcelona, Crítica, 1981.

Tomás y Valiente, Francisco, «Origen bajomedieval de la patrimonialización y la enajenación de oficios públicos en Castilla», Actas del I Symposium de Historia de la Administración Madrid, Instituto de Estudios Administrativos, 1970; 123-159.

Valdeón Baruque, Julio, «La articulación de las sociedades urbanas», José Ignacio Iglesia Duarte (ed.), Las sociedades urbanas en la España Medieval: XXIX Semana de Estudios Medievales, Pamplona, 2003; 81-95.

Valdeón Baruque, Julio y Esteban Recio, Asunción, «Esbozo de una geografía social. Palencia a fines de la Edad Media», Studia Histórica, Historia Medieval, III/2 (Salamanca, 1985): 117-141.

Valdeón Baruque, Julio, «Las oligarquías urbanas», Concejos y ciudades en la Edad Media Hispánica. II Congreso de Estudios Medievales, Madrid, Fundación Sánchez Albornoz, 1990; 507-537.

Valdeón Baruque, Julio, Los conflictos sociales en el reino de Castilla en los siglos $X I V$ y $X V$, Madrid, Siglo XXI, 1983.

Valle García, Rafael, El reinado de Isabel la Católica a la luz de los documentos del Archivo Municipal de Palencia, Palencia, Institución Tello Téllez de Meneses, 2007.

Vicens Vives, Jaume, Historia de los Remensas en el siglo XV, Barcelona, CSIC, 1944.

Recibido: 21/10/2013

Aceptado: 08/09/2014 